\title{
Methodiek arbeidsmarktprognoses en -indicatoren 2005-2010
}

Citation for published version (APA):

Cörvers, F., Dupuy, A., Dijksman, S., Golsteyn, B., Kriechel, B., \& Montizaan, R. (2006). Methodiek arbeidsmarktprognoses en -indicatoren 2005-2010. ROA. ROA Working Papers No. 006 https://doi.org/10.26481/umarow.2006006

Document status and date:

Published: 01/01/2006

DOI:

10.26481/umarow.2006006

Document Version:

Publisher's PDF, also known as Version of record

\section{Please check the document version of this publication:}

- A submitted manuscript is the version of the article upon submission and before peer-review. There can be important differences between the submitted version and the official published version of record.

People interested in the research are advised to contact the author for the final version of the publication, or visit the DOI to the publisher's website.

- The final author version and the galley proof are versions of the publication after peer review.

- The final published version features the final layout of the paper including the volume, issue and page numbers.

Link to publication

\footnotetext{
General rights rights.

- You may freely distribute the URL identifying the publication in the public portal. please follow below link for the End User Agreement:

www.umlib.nl/taverne-license

Take down policy

If you believe that this document breaches copyright please contact us at:

repository@maastrichtuniversity.nl

providing details and we will investigate your claim.
}

Copyright and moral rights for the publications made accessible in the public portal are retained by the authors and/or other copyright owners and it is a condition of accessing publications that users recognise and abide by the legal requirements associated with these

- Users may download and print one copy of any publication from the public portal for the purpose of private study or research.

- You may not further distribute the material or use it for any profit-making activity or commercial gain

If the publication is distributed under the terms of Article $25 \mathrm{fa}$ of the Dutch Copyright Act, indicated by the "Taverne" license above, 
Methodiek arbeidsmarktprognoses en -indicatoren 2005-2010

ROA-W-2006/6

F. Cörvers, A. Dupuy, S. Dijksman, B. Golsteyn, B. Kriechel, R. Montizaan

Researchcentrum voor Onderwijs en Arbeidsmarkt

Faculteit der Economische Wetenschappen en Bedrijfskunde Universiteit Maastricht

Maastricht, september 2006 
ISBN-10: 90-5321-443-7

ISBN-13: 978-90-5321-443-5

Sec06.094.doc 


\section{Inhoud}

Pagina

Voorwoord

1 Inleiding

2 Structuur van de gepresenteerde arbeidsmarktinformatie

3 De actuele situatie op de arbeidsmarkt 4

3.1 Inleiding 4

3.2 De berekening van de trend 5

$\begin{array}{lll}3.3 \text { Toelichting op de variabelen voor de actuele arbeidsmarktsituatie } & 6\end{array}$

4 Methodiek arbeidsmarktprognoses 11

4.1 Inleiding 11

4.2 Methodiek uitbreidingsvraag 12

$\begin{array}{ll}4.3 \text { Methodiek vervangingsvraag } & 20\end{array}$

4.4 Methodiek instroom van schoolverlaters op de arbeidsmarkt 25

4.5 Baanopeningen en typering arbeidsmarktperspectieven 31

4.6 Typering knelpunten in de personeelsvoorziening 32

5 De structurele arbeidsmarktsituatie $\quad 34$

5.1 Inleiding 34

5.2 Conjunctuurgevoeligheid $\quad 35$

$\begin{array}{ll}5.3 \text { Uitwijk- en substitutiemogelijkheden } & 36\end{array}$

$\begin{array}{ll}5.4 \text { Concurrentie-index } & 37\end{array}$

$\begin{array}{ll}\text { Literatuur } & 37\end{array}$

$\begin{array}{ll}\text { Appendix A } & 41\end{array}$ 



\section{Voorwoord}

De weergave van de methodiek in dit werkdocument heeft betrekking op het samenstellen van de arbeidsmarktinformatie over 34 bedrijfssectoren, 127 beroepsgroepen en 102 opleidingstypen die is gebruikt in het rapport De arbeidsmarkt naar opleiding en beroep tot 2010. Dit rapport is in november 2005 uitgebracht in het kader van het Project Onderwijs-Arbeidsmarkt (POA) van het ROA. Het rapport biedt een overzicht van de huidige en toekomstige ontwikkelingen op de Nederlandse arbeidsmarkt in de periode 2005-2010. Het gepresenteerde overzicht heeft als doel inzicht te verschaffen in de actuele situatie en de prognoses van beroepen en opleidingen op de arbeidsmarkt. De prognoses worden elke twee jaar herhaald voor een nieuwe periode van vijf jaar. De beschrijvingen en analyses in het rapport spitsen zich toe op de grote lijnen van de huidige en toekomstige arbeidsmarktontwikkelingen.

In bijlage C van De arbeidsmarkt naar opleiding en beroep tot 2010 en op de website van het ROA (http://www.roa.unimaas.nl) wordt een overzicht van de beschikbare arbeidsmarktinformatie naar bedrijfssector, beroepsgroep en opleidingstype gegeven. Deze informatie is op aanvraag bij het ROA verkrijgbaar. Voor de financiers van POA is het zogenaamde ArbeidsmarktInformatieSysteem (AIS) beschikbaar, waarmee gebruikers zelf op eenvoudige wijze de gewenste tabellen kunnen samenstellen.

Het Project Onderwijs-Arbeidsmarkt wordt gefinancierd door het Ministerie van Onderwijs, Cultuur en Wetenschap (OCW), het Centrum voor Werk en Inkomen (CWI), het Ministerie van Landbouw, Natuur en Voedselkwaliteit (LNV), de vereniging kenniscentra beroepsonderwijs bedrijfsleven COLO, Randstad Nederland en de Raad voor Werk en Inkomen (RWI). 



\section{Inleiding}

In dit werkdocument wordt ingegaan op de databronnen, de definities van een aantal begrippen, en de prognosemethodiek die zijn gebruikt bij het rapport De arbeidsmarkt naar opleiding en beroep tot 2010 (ROA, 2005). In het rapport wordt reeds ingegaan op het doel van de arbeidsmarktprognoses, en een beknopte weergave van de gehanteerde methodiek met een beschrijving van de centrale begrippen gegeven. De uitgangspunten van het Project Onderwijs-Arbeidsmarkt en de prognosemethodiek zijn uitgebreider uiteengezet in verschillende andere publicaties. ${ }^{1}$ Voor een aantal specifieke onderdelen van de prognosemethodiek zijn tevens afzonderlijke werkdocumenten verschenen. Om die reden wordt in dit werkdocument voor deze aspecten slechts een globaal overzicht van de gehanteerde methodiek en het doel van de arbeidsmarktprognoses gegeven. Voor een meer gedetailleerde beschrijving wordt verwezen naar het op het desbetreffende onderdeel toegespitste werkdocument. Zie daarvoor tevens de referenties bij de centrale begrippen in Bijlage A van De arbeidsmarkt naar opleiding en beroep tot 2010 (ROA, 2005).

De arbeidsmarktprognoses naar opleiding en beroep vormen een belangrijk onderdeel van de beschikbare arbeidsmarktinformatie. In dit werkdocument wordt een actualisatie gegeven van de beschrijving van de prognosemethodiek in Cörvers e.a. (2004) bij de vorige uitgave De arbeidsmarkt naar opleiding en beroep tot 2008 (ROA, 2003).

De opzet van dit werkdocument is als volgt. In hoofdstuk 2 wordt de structuur van het informatiesysteem besproken. Vervolgens wordt in hoofdstuk 3 ingegaan op de actuele data in het informatiesysteem. In hoofdstuk 4 wordt de prognosemethodiek besproken en in hoofdstuk 5 wordt ingegaan op de indicatoren met betrekking tot de structurele kenmerken van de arbeidsmarkt.

\section{Structuur van de gepresenteerde arbeidsmarktinformatie}

Het doel van het Project Onderwijs-Arbeidsmarkt is om inzicht te verschaffen in de actuele en de op middellange termijn verwachte situatie op de arbeidsmarkt, verbijzonderd naar beroep en opleiding. Met dit transparant maken van de arbeidsmarkt wordt beoogd dat de bij onderwijs en arbeidsmarkt betrokken partijen beter inzicht hebben in de huidige en toekomstige ontwikkelingen in de aansluiting tussen onderwijs en arbeidsmarkt, zodat zij meer adequate beslissingen kunnen nemen. Hierdoor zullen discrepanties tussen vraag en aanbod op de arbeidsmarkt kunnen verminderen. Relevante betrokkenen zijn leerlingen, scholen, de overheid, de arbeidsvoorzieningsorganisatie en bedrijven. Door de verstrekte informatie kan een leerling die een studiekeuze maakt zich oriënteren op de arbeidsmarktperspectieven op het moment dat hij of zij de studie zal afronden, en krijgen aanbieders van onderwijs meer inzicht in de relevantie van hun opleidingenaanbod voor de verwachte vraag naar personeel op de middellange termijn. De structuur van de gegenereerde informatie sluit

1. Zie o.a. Borghans, De Grip en Willems (1995), Van Eijs en De Grip (1998), Borghans, De Grip en Heijke (2000), Cörvers, De Grip en Heijke (2002), Cörvers (2003) en Cörvers en Heijke (2004). 
hierbij aan door voor zowel beroepen als voor opleidingen kengetallen te presenteren met betrekking tot de actuele situatie op de arbeidsmarkt en de arbeidsmarktsituatie over vijf jaar. Ook voor andere partijen die betrokken zijn bij het onderwijs is het van belang dat er vooruit wordt gekeken. Dit voorkomt een pro-cyclisch beleid, dat te sterk reageert op de actuele arbeidsmarktsituatie. Naast de perspectieven voor schoolverlaters zoals die zijn weergegeven in de Indicator Toekomstige Arbeidsmarktperspectieven (ITA), wordt ook ingegaan op het perspectief van de werkgever. Middels de Indicator Toekomstige Knelpunten in de Personeelsvoorziening (ITKP) en de Indicator Toekomstige Knelpunten in de Personeelsvoorziening naar Beroep (ITKB) wordt aangegeven voor welke opleidingstypen en beroepsgroepen wervingsproblemen te verwachten zijn.

Het arbeidsmarktinformatiesysteem van POA is opgebouwd uit drie componenten. De informatie over de actuele situatie geeft aan hoe thans de positie van werkenden en schoolverlaters met een bepaalde opleidingsachtergrond is. Het arbeidsmarktperspectief van de verschillende opleidingstypen geeft op grond van de verwachte kwantitatieve verschuivingen in vraag en aanbod aan hoe deze positie zich de komende vijf jaar zal ontwikkelen. Ten slotte plaatsen de structurele kenmerken van de arbeidsmarktpositie de positie van een bepaalde opleiding of beroep in een ruimer perspectief.

De actuele informatie is in principe gebaseerd op gerealiseerde gegevens over het jaar 2004 of het gemiddelde van de afgelopen twee jaren (2003-2004). ${ }^{2}$ Zo wordt een beeld gegeven van de absolute en relatieve omvang van het totaal aantal werkenden in een beroepsgroep en de omvang van de potentiële beroepsbevolking en het aantal werkenden met een bepaalde opleidingsachtergrond. Deze aantallen werkenden worden vervolgens ook verbijzonderd naar persoonlijke kenmerken als geslacht, etniciteit en leeftijd en naar de functiekenmerken: vast werk, deeltijdarbeid, e.d. Voor de onderscheiden opleidingstypen wordt bovendien getracht een beeld te geven van de actuele aansluitingsproblemen op de arbeidsmarkt, zowel wat betreft het percentage werkloze schoolverlaters, als de mate waarin er sprake is van onderbenutting.

Bij de middellangetermijnprognoses wordt zowel voor beroepsgroepen als opleidingstypen het verwachte aantal baanopeningen aangegeven. Deze vraag naar nieuwkomers is uitgesplitst naar de vraag als gevolg van nieuwe banen (uitbreidingsvraag) en de vervangingsvraag. Voor de opleidingen wordt daarnaast ook de instroom van nieuwkomers op de arbeidsmarkt voorspeld, zodat vraag en aanbod aan elkaar kunnen worden gerelateerd. Op basis van deze confrontatie en de substitutieprocessen die hierdoor op gang zullen komen, wordt een indicator van de verwachte arbeidsmarktsituatie voor de onderscheiden opleidingstypen opgesteld. Op vergelijkbare wijze worden ook de verwachte knelpunten in de personeelsvoorziening in kaart gebracht, waarbij bovendien per bedrijfssector de opleidingstypen met de grootste knelpunten worden aangeduid. Ook voor de

2. De gegevens over werkenden en schoolverlaters in het arbeidsmarktinformatiesysteem (AIS) worden jaarlijks geactualiseerd, in tegenstelling tot de prognosegegevens die tweejaarlijks worden geactualiseerd. Dit betekent dat de gegevens over werkenden (gem. 2004-2005) en schoolverlaters (2005) in de loop van 2006 worden geactualiseerd. 
beroepsgroepen wordt een indicator opgesteld van de verwachte knelpunten in de personeelsvoorziening.

De structurele kenmerken van de arbeidsmarktpositie zijn eveneens afgeleid uit gerealiseerde gegevens. Enerzijds verdiepen deze indicatoren het inzicht in de huidige arbeidsmarktpositie. Anderzijds zijn deze indicatoren een aanvulling op de prognoses, doordat ze aangeven in hoeverre een beroep c.q. opleiding afhankelijk is van de ontwikkeling in een enkele bedrijfssector of beroepsgroep, in hoeverre het beroependomein van een opleidingstype gerelateerd is aan het beroependomein van andere opleidingstypen en in welke mate de werkgelegenheid gevoelig is voor de conjuncturele ontwikkelingen. Op deze wijze fungeren deze indicatoren als risico-indicatoren.

Binnen het informatiesysteem worden de actuele data, de prognoses en de structurele kenmerken telkens op kwalitatieve wijze getypeerd. Met uitzondering van de indicatoren voor de toekomstige arbeidsmarktsituatie wordt hierdoor aangegeven wat op het desbetreffende punt de relatieve positie van het beroep of de opleiding is ten opzichte van de andere beroepen, respectievelijk opleidingen. Doorgaans vinden de typeringen plaats op basis van een vijf-puntsschaal, lopend van erg hoog, hoog, gemiddeld, laag, tot erg laag. De kwalitatieve typering zorgt ervoor dat de cijfers eenvoudiger zijn te interpreteren en dat schijnnauwkeurigheden worden vermeden. De typeringen hebben plaatsgevonden op basis van een methodiek beschreven in Wieling, De Grip en Willems (1990). Daarbij wordt tevens enigszins van deze procedure afgeweken door de berekende grenzen tussen de typeringsintervallen af te ronden. In appendix A wordt voor alle variabelen in het informatiesysteem aangegeven welke grenzen zijn gehanteerd bij de kwalitatieve typering.

Bij de gepresenteerde informatie per beroepsgroep en opleidingstype wordt er ook een expliciete relatie gelegd tussen beroepen en opleidingen. Per opleidingstype wordt een overzicht gegeven van de belangrijkste beroepsgroep waarin men werkzaam is en voor elke beroepsgroep wordt de opleidingsachtergrond van de werkenden in beeld gebracht. Een vergelijkbare relatie is ook gelegd tussen bedrijfssectoren en beroepsgroepen of opleidingstypen.

Voor gebruikers van de arbeidsmarktinformatie is het doorgaans wenselijk om de beroepen en de opleidingen op een zo gedetailleerd mogelijk niveau in beeld te brengen. Deze detaillering kent echter haar grenzen in de beschikbaarheid van de basisgegevens, die voor een groot deel afkomstig zijn uit de Enquête Beroepsbevolking (EBB) van het Centraal Bureau voor de Statistiek (CBS). De onzekerheidmarges waarmee de EBB-cijfers zijn omgeven leggen een ondergrens op aan de mate van detaillering die in het informatiesysteem voor beroepen en opleidingen kan worden toegepast. Voor de EBB-gegevens geldt een ondergrens voor de aantallen personen die in de tabellen gepubliceerd mogen worden. Voor jaarcijfers is dat minimaal 5.000 werkenden, voor meerjaarsgemiddelden is dat minimaal 2.500 werkenden. Ook kunnen gegevens worden gepubliceerd die gebaseerd zijn op een randtotaal van 30.000 werkenden voor één jaar en 15.000 werkenden voor het gemiddelde van twee jaren Waar deze ondergrens niet werd bereikt wordt in de overzichtstabellen het betreffende getal met een '-' aangegeven. Andere belangrijke 
informatiebronnen zijn de schoolverlatersenquêtes BVE-Monitor, HBO-Monitor en de WOMonitor, welke tezamen beschikbaar zijn in het SchoolverlatersInformatieSysteem (SIS, zie ROA 2005a). Bij de presentatie van gegevens uit deze databestanden is een ondergrens van 15 respondenten gehanteerd.

Voor de bruikbaarheid van de prognoses, actuele informatie en indicatoren is het van belang dat de gehanteerde opleidingsindeling zo goed mogelijk aansluit bij de op de arbeidsmarkt bestaande deelmarkten. Heijke, Matheeuwsen en Willems (2003) hebben daarom de opleidingsrichtingen vanuit een arbeidsmarktperspectief geclusterd. Er worden thans 113 opleidingstypen onderscheiden, die gekoppeld zijn aan de Standaard Onderwijsindeling 1978 (SOI '78) van het CBS. In totaal wordt voor 102 opleidingstypen actuele informatie en arbeidsmarktprognoses verstrekt. De gegevens met betrekking tot het MBO-niveau uit zowel de EBB als de schoolverlatersenquêtes zijn gebaseerd op de in de Wet Educatie en Beroepsonderwijs (WEB) onderscheiden leerwegen. ${ }^{3}$

Voor de arbeidsmarktinformatie naar beroep is gebruik gemaakt van de Standaard Beroepenclassificatie 1992 (SBC '92) van het CBS. Hierdoor wordt de vergelijkbaarheid met andere informatiebronnen over de arbeidsmarkt sterk vergroot. Omdat het CBS de beroepsgroepen aanduidt met vrij abstracte termen, heeft het ROA wel andere benamingen voor deze beroepsgroepen gehanteerd. Uitgangspunt hierbij is dat de namen kort en herkenbaar moeten zijn, en daarnaast een zo groot mogelijk deel van de onderliggende beroepen, gemeten in het aantal werkzame personen, gerepresenteerd moet worden. Op een aantal punten is de CBS-classificatie verder verbijzonderd. De door het CBS onderscheiden elementaire beroepen zijn opgesplitst in zes beroepsgroepen. Ook de beroepsgroep 471 middelbare procestechnische beroepen was dermate heterogeen dat deze is opgesplitst in 471a procesoperators en 471b bakkers en slagers. In de ROA-classificatiegids 2002 (ROA, 2002) worden uitgebreide overzichten gegeven van de namen en coderingen van de sectoren, beroepen en opleidingen die binnen POA gehanteerd worden en de koppelingen tussen de classificaties naar opleiding, beroep en sector van het CBS en het ROA. In de loop der tijd hebben verschillende benamingen voor opleidingstypen en beroepsgroepen kleine wijzigingen ondergaan, zonder dat de classificaties als zodanig zijn veranderd. Het meest recente overzicht van de benamingen is terug te vinden in Bijlage $B$ van De arbeidsmarkt naar opleiding en beroep tot 2010 (ROA, 2005).

\section{De actuele situatie op de arbeidsmarkt}

\subsection{Inleiding}

In dit hoofdstuk wordt een overzicht gegeven van de gegevens in het informatiesysteem met betrekking tot de actuele arbeidsmarktpositie vanuit de invalshoek van bedrijfssectoren, beroepsgroepen en opleidingstypen. De gegevens die betrekking hebben op de gehele

3. Zie voor een toelichting op de opleidingbenamingen in de WEB en het VMBO Bijlage B in De arbeidsmarkt naar opleiding en beroep tot 2004 (ROA, 1999). 
werkzame beroepsbevolking zijn gebaseerd op de Enquête Beroepsbevolking (EBB) van het CBS. De gegevens hebben betrekking op het gemiddelde aantal werkenden in de jaren 2003 en 2004. Naast de informatie over de actuele arbeidsmarktpositie van de werkzame beroepsbevolking naar opleiding, wordt er aanvullende informatie gegeven over de positie van schoolverlaters. Deze schoolverlatersinformatie is gebaseerd op de schoolverlatersenquêtes RUBS, de HBO-Monitor en de WO-Monitor, welke geïntegreerd zijn in het SchoolverlatersInformatieSysteem (SIS) van het ROA. Voor het AVO, VBO en MBO is gebruik gemaakt van RUBS 2004, terwijl de gegevens over het HBO en het WO gebaseerd zijn op respectievelijk de HBO-Monitor 2004 en WO-Monitor 2004 (zie ook ROA, 2005a). In deze schoolverlatersenquêtes zijn in het najaar van 2004 over de volle breedte van het onderwijsstelsel schoolverlaters en afgestudeerden geënquêteerd ongeveer anderhalf jaar na het voltooien van hun opleiding (schooljaar 2002/2003).

Naast de in hoofdstuk 2 genoemde kwalitatieve typering van de verschillende cijfers, wordt voor de actuele data in de meeste gevallen ook de ontwikkeling (trend) van de desbetreffende cijfers getypeerd, variërend van sterk dalend tot sterk stijgend. Alvorens in te gaan op de actuele data die gepresenteerd zijn in De arbeidsmarkt naar opleiding en beroep tot 2010 en het bijbehorende ArbeidsmarktInformatieSysteem (AIS), wordt in de volgende paragraaf ingegaan op de bepaling van deze trends.

\subsection{De berekening van de trend}

Uitgangspunt van de methodiek om de trend vast te stellen is een exponentieel model dat wordt geschat en waarin de ontwikkeling van $x_{t}$ wordt verklaard uit een constante term $\alpha$ en een trendvariabele $t, t=1, \ldots ., n$ :

$$
\ln \left(x_{t}\right)=\alpha+\beta t
$$

De OLS-schatting voor $\beta$ vormt de trend-indicator. Omdat de (natuurlijke) logaritme van de te verklaren variabele is genomen in de vergelijking kan deze indicator geïnterpreteerd worden als de jaarlijkse procentuele groei. De expliciete vergelijking maakt het mogelijk deze trend ook te berekenen voor tijdreeksen met een ontbrekende waarneming. De interpretatie van de indicator is onafhankelijk van de gehanteerde reeks. Wel blijken korte tijdreeksen over het algemeen sterkere trends te vertonen dan langere reeksen. Bij de langere reeksen vallen tegengestelde bewegingen immers tegen elkaar weg.

Op basis van een analyse van de trends is vastgesteld dat een trendberekening op basis van een vijfjarige tijdreeks het meest geschikt is. Bij het bepalen van de trends is derhalve uitgegaan van de ontwikkelingen in de jaren 2000-2004.

De OLS-schatter voor $\beta$ is voor een reeks van vijf jaren de facto gelijk aan:

$$
\hat{\beta}=-\frac{2}{10} \ln \left(x_{1}\right)-\frac{1}{10} \ln \left(x_{2}\right)+\frac{1}{10} \ln \left(x_{4}\right)+\frac{2}{10} \ln \left(x_{5}\right)
$$


Naast de trendschatting zelf is ook de standaarddeviatie van de geschatte trend berekend. Tijdreeksen met een grillig verloop kunnen per toeval een zeer sterke trendwaarde opleveren. De trend wordt daarom niet meer gepresenteerd als de standaarddeviatie $(s d)$ te groot is:

$\left|\frac{\text { trend }}{s d}\right|<1$

Evenals de actuele data, de structurele gegevens en de prognoses zijn ook de trendmatige ontwikkelingen kwalitatief getypeerd. Voor elke variabele is dezelfde indeling gehanteerd.

$$
\begin{array}{rlll} 
& \text { trend } \leq-0,10 & \text { sterk dalend } \\
-0,10< & \text { trend } \leq-0,03 & \text { dalend } \\
-0,03< & \text { trend } \leq 0,03 & \text { constant } \\
0,03< & \text { trend } \leq 0,10 & \text { stijgend } \\
0,10< & \text { trend } & & \text { sterk stijgend }
\end{array}
$$

De trendwaarden kunnen rechtstreeks geïnterpreteerd worden als gemiddelde jaarlijkse groei. Overigens dient opgemerkt te worden dat de trend betrekking kan hebben op zowel de absolute waarde (bijv. het aantal werkenden), als de relatieve omvang van een variabele (bijv. het percentage allochtonen van de werkzame beroepsbevolking). In de volgende paragrafen zal bij iedere variabele worden aangegeven welke invalshoek is gehanteerd bij het vaststellen van de trend.

\subsection{Toelichting op de variabelen voor de actuele arbeidsmarktsituatie}

In deze paragraaf wordt een technische toelichting gegeven op de variabelen die in het informatiesysteem van het Project Onderwijs-Arbeidsmarkt (POA) zijn opgenomen voor een beschrijving van de actuele situatie op de arbeidsmarkt. ${ }^{4}$ In tabel 3.1 zijn de definities van de variabelen weergegeven. Daarnaast wordt in de tabel aangegeven op welke indeling deze variabele betrekking heeft, i.e. naar bedrijfssector, beroepsgroep of opleidingstype, en uit welke bron de gegevens afkomstig zijn. Deze bron kan betrekking hebben op zowel de Enquête Beroepsbevolking (EBB) van het CBS als het SchoolverlatersInformatieSysteem (SIS) van het ROA. Meer informatie over de EBB-variabelen is weergegeven in tabel 3.1. Voor de variabelen waarvoor een trend is vastgesteld, wordt aangegeven of de trend gebaseerd is op de ontwikkeling van de absolute aantallen werkzame personen of het werkgelegenheidsaandeel.

4. Zie paragraaf 5 voor een toelichting op de variabelen die betrekking hebben op de structurele arbeidsmarktsituatie, i.e. de conjunctuurgevoeligheid, de uitwijk- en substitutiemogelijkheden en de concurrentie-index. 
Tabel 3.1

Technische toelichting op de variabelen over de actuele situatie op de arbeidsmarkt, EBB-variabelen in het ArbeidsmarktInformatieSysteem (AIS)

\section{Aantal werkenden}

beschikbaar

trend

\section{Arbeidsvolume \\ beschikbaar \\ trend \\ Arbeidsmarktpositie potentiële beroepsbevolking}

beschikbaar

trend

\section{Werkzame beroepsbevolking}

beschikbaar trend
Het aantal werkenden heeft betrekking op iedereen die jonger is dan 65 en minstens 12 uur per week werkt. bedrijfssector, beroepsgroep, opleidingstype ja, absolute aantallen werkenden

Arbeidsvolume is het totaal aantal normaal gewerkte arbeidsuren gedeeld door 40 .

bedrijfssector, beroepsgroep, opleidingstype nee

De potentiële beroepsbevolking betreft alle mensen die ouder zijn dan 15 en jonger dan 65, uitgezonderd studenten en scholieren. Er worden vier arbeidsmarktposities onderscheiden:

- Werkzame beroepsbevolking;

- Werkloze beroepsbevolking;

- Beschikbare niet-beroepsbevolking;

- Niet beschikbare niet-beroepsbevolking.

Tot de beroepsbevolking behoren degenen die (1) tenminste twaalf uur per week werken, of (2) personen die werk hebben aanvaard waardoor ze tenminste twaalf uur per week gaan werken, of (3) personen die verklaren ten minste twaalf uur per week te willen werken, daarvoor beschikbaar zijn en activiteiten ontplooien om werk voor ten minste twaalf uur per week te vinden. Van de beroepsbevolking worden personen die ten minste twaalf uur per week werken tot de werkzame beroepsbevolking gerekend en degenen die niet of minder dan twaalf uur per week werken tot de werkloze beroepsbevolking (definities CBS).

opleidingstype

nee

De werkzame beroepsbevolking is het aantal werkenden uitgedrukt als percentage van de potentiële beroepsbevolking.

opleidingstype

nee

Werkloze beroepsbevolking De werkloze beroepsbevolking is het aantal werklozen uitgedrukt als percentage van de potentiële beroepsbevolking. Het weergegeven werkloosheidpercentage dient niet verward te worden met het gebruikelijke werkloosheidspercentage, waarin de werkloosheid gerelateerd wordt aan de beroepsbevolking.

beschikbaar opleidingstype

trend nee 
Tabel 3.1 (vervolg)

Technische toelichting op de variabelen over de actuele situatie op de arbeidsmarkt, EBB-variabelen in het ArbeidsmarktInformatieSysteem (AIS)

\author{
Beschikbare niet- \\ Alle personen van 15 tot 65 jaar die niet tot de beroepsbevolking \\ beroepsbevolking \\ behoren en binnen twee weken in een nieuwe werkkring kunnen \\ beginnen. \\ beschikbaar \\ trend \\ opleidingstype \\ nee \\ Niet beschikbare niet- \\ Alle personen van 15 tot 65 jaar die niet tot de beroepsbevolking \\ beroepsbevolking \\ behoren en binnen twee weken in een nieuwe werkkring kunnen \\ beginnen. \\ beschikbaar \\ opleidingstype \\ trend \\ nee \\ Percentage vrouwen \\ beschikbaar \\ trend \\ bedrijfssector, beroepsgroep, opleidingstype \\ ja, werkgelegenheidsaandeel \\ Percentage niet-westerse \\ allochtonen \\ Het percentage allochtonen naar herkomst heeft betrekking op \\ iedereen waarvan ten minste één ouder in het buitenland is geboren. \\ Tot de niet-westerse herkomstlanden worden gerekend Turkije en alle \\ landen in Afrika, Latijns-Amerika en Azië (met uitzondering van Japan \\ en Indonesië). \\ beschikbaar \\ bedrijfssector, beroepsgroep, opleidingstype \\ trend \\ ja, werkgelegenheidsaandeel
}

Percentage jongeren en

De jongeren betreft alle mensen die ouder dan 15 jaar en jonger dan ouderen 30 jaar zijn. Voor de ouderen geldt dat ze ouder dan 50 jaar en jonger dan 65 jaar zijn.

beschikbaar

bedrijfssector, beroepsgroep, opleidingstype

trend

ja, werkgelegenheidsaandeel

Gemiddelde leeftijd

beschikbaar

trend

beroepsgroep, opleidingstype

nee

Percentage deeltijdarbeid

beschikbaar

Deeltijdarbeid betreft personen die hoogstens 32 uur maar minstens

12 uur per week werkzaam zijn.

trend

bedrijfssector, beroepsgroep, opleidingstype

ja, werkgelegenheidsaandeel

Gemiddeld aantal uren per Gemiddeld aantal uren per week dat men werkzaam is.

week

beschikbaar

bedrijfssector, beroepsgroep, opleidingstype

trend

nee 
Tabel 3.1 (vervolg)

Technische toelichting op de variabelen over de actuele situatie op de arbeidsmarkt, EBB-variabelen in het ArbeidsmarktInformatieSysteem (AIS)

\begin{tabular}{ll}
\hline Percentage flexibel werk & $\begin{array}{l}\text { Van een flexibele arbeidsrelatie is sprake bij werknemers die werken } \\
\text { als uitzend-, oproep-, of invalskrachten en bij werknemers met } \\
\text { contracten zonder een vast aantal arbeidsuren of zonder dat een vast } \\
\text { dienstverband is overeengekomen. Een arbeidscontract wordt als niet- } \\
\text { vast beschouwd als de contractuele termijn korter is dan een jaar en er }\end{array}$ \\
& geen vooruitzicht is op een vast dienstverband. \\
bedrijfssector, beroepsgroep, opleidingstype \\
beschikbaar & ja, werkgelegenheidsaandeel
\end{tabular}

Percentage vast werk beschikbaar trend

Percentage zelfstandigen

beschikbaar

trend

\section{Belangrijkste beroepsgroepen}

beschikbaar

trend

\section{Belangrijkste bedrijfssectoren}

beschikbaar

trend

\section{Belangrijkste opleidingstypen}

beschikbaar trend
Dit betreft alle werknemers die geen flexibele arbeidsrelatie hebben. bedrijfssector, beroepsgroep, opleidingstype

ja, werkgelegenheidsaandeel

Het begrip zelfstandig bevat ook personen die werkzaam zijn in het bedrijf of de praktijk van hun partner of ouders en freelancers e.d. bedrijfssector, beroepsgroep, opleidingstype ja, werkgelegenheidsaandeel

Hierin zijn alle beroepsgroepen opgenomen die ten minste betrekking hebben op $2,5 \%$ van de totale werkgelegenheid in de desbetreffende bedrijfssector/opleidingstype.

bedrijfssector, opleidingstype

ja, werkgelegenheidsaandeel

Hierin zijn alle bedrijfssectoren opgenomen die ten minste betrekking hebben op 2,5\% van de totale werkgelegenheid in de desbetreffende beroepsgroep/opleidingstype.

beroepsgroep, opleidingstype

ja, werkgelegenheidsaandeel

Hierin zijn alle opleidingstypen opgenomen die ten minste betrekking hebben op $2,5 \%$ van de totale werkgelegenheid in de desbetreffende bedrijfssector/beroepsgroep.

bedrijfssector, beroepsgroep

ja, werkgelegenheidsaandeel 
Tabel 3.2

Technische toelichting op de variabelen over de actuele situatie op de arbeidsmarkt, SIS-variabelen in het ArbeidsmarktInformatieSysteem (AIS)

\begin{tabular}{|c|c|}
\hline $\begin{array}{l}\text { Participatie schoolverlaters } \\
\text { in vervolgopleidingen }\end{array}$ & $\begin{array}{l}\text { In de Wet Educatie en Beroepsonderwijs (WEB) waarin de nieuwe } \\
\text { kwalificatiestructuur voor het MBO is vastgelegd, wordt onderscheid } \\
\text { gemaakt tussen de beroepsopleidende leerweg (BOL) en de } \\
\text { beroepsbegeleidende leerweg (BBL). Deze laatste is vergelijkbaar met } \\
\text { het voormalige leerlingwezen. } \\
\text { opleidingstype }\end{array}$ \\
\hline trend & nee \\
\hline
\end{tabular}

Percentage schoolverlaters $\mathrm{Er}$ is gevraagd of schoolverlaters achteraf gezien liever een andere met spijt van de gevolgde opleiding hadden willen kiezen.

opleiding

beschikbaar

opleidingstype

trend

nee

Percentage schoolverlaters Het percentage is gemeten in procenten van de schoolverlaters die tot met een intredewerkde beroepsbevolking behoren. Onder intredewerkloosheid wordt het loosheid van 4 maanden of langer totaal aantal maanden verstaan dat schoolverlaters sinds het verlaten van de opleiding als werkloos hebben opgegeven.

beschikbaar

opleidingstype

trend

nee

\section{Percentage werkloze schoolverlaters}

beschikbaar

trend

Percentage deeltijdarbeid

onder werkzame

schoolverlaters

beschikbaar

trend

Gemiddeld bruto maand-

loon van werkzame

schoolverlaters

beschikbaar

trend
Het percentage is gemeten in procenten van de schoolverlaters die tot de beroepsbevolking behoren. De definities van werkloosheid en beroepsbevolking zijn dezelfde als die van het CBS (zie tabel 3.1).

opleidingstype

nee

Deeltijdarbeid betreft de schoolverlaters die hoogstens 32 uur maar minstens 12 uur per week werkzaam zijn.

opleidingstype

nee

Het bruto maandloon is samengesteld op basis van een voltijdaanstelling.

opleidingstype

nee

De eigen of een verwante opleidingsrichting is niet vereist voor een

Percentage werkzame schoolverlaters met functie buiten de vakrichting

beschikbaar

trend opleidingstype

nee 
Tabel 3.2 (vervolg)

Technische toelichting op de variabelen over de actuele situatie op de arbeidsmarkt, SIS-variabelen in het ArbeidsmarktInformatieSysteem (AIS)

\begin{tabular}{|c|c|}
\hline $\begin{array}{l}\text { Percentage werkzame } \\
\text { schoolverlaters van wie } \\
\text { kwalificaties worden } \\
\text { onderbenut }\end{array}$ & $\begin{array}{l}\text { Onderbenutting wordt bepaald op basis van het opleidingsniveau dat } \\
\text { vereist is voor de functie. }\end{array}$ \\
\hline $\begin{array}{l}\text { beschikbaar } \\
\text { trend }\end{array}$ & $\begin{array}{l}\text { opleid } \\
\text { nee }\end{array}$ \\
\hline $\begin{array}{l}\text { Percentage werkzame } \\
\text { schoolverlaters met vast } \\
\text { dienstverband } \\
\text { beschikbaar } \\
\text { trend }\end{array}$ & $\begin{array}{l}\text { Conform definitie van werknemers met een vast dienstverband in tabe } \\
\text { 3.1. } \\
\text { opleidingstype } \\
\text { nee }\end{array}$ \\
\hline $\begin{array}{l}\text { Percentage werkzame } \\
\text { schoolverlaters in het MKB } \\
\text { beschikbaar } \\
\text { trend }\end{array}$ & $\begin{array}{l}\text { Het gaat om schoolverlaters die werken in een bedrijf of instelling van } \\
\text { minder dan } 100 \text { werkenden. } \\
\text { opleidingstype } \\
\text { nee }\end{array}$ \\
\hline
\end{tabular}

Gemiddelde reistijd/afstand De reisafstand en reistijd van thuis naar het werk in kilometers van werkzame schoolverlaters beschikbaar opleidingstype trend nee

\section{Methodiek arbeidsmarktprognoses}

\subsection{Inleiding}

In dit hoofdstuk wordt ingegaan op de gehanteerde onderzoeksmethoden van de middellangetermijnprognoses naar beroepsgroep en opleidingstype voor de periode 20052010. In de inleiding 'Doel en opzet van de arbeidsmarktprognoses' van De arbeidsmarkt naar opleiding en beroep tot 2010 (ROA, 2005) wordt een globaal overzicht gegeven van het prognosemodel van het informatiesysteem. Daarbij wordt tevens een overzicht gegeven van welke prognoses over de economie en de arbeidsmarkt zijn ontleend aan andere bronnen (o.a. van CPB en OCW). Deze overzichten zullen hier niet worden herhaald, maar aansluitend daarop zal meer specifiek op de verschillende prognose-onderdelen worden ingegaan. Achtereenvolgens zal de methodiek van de uitbreidingsvraagprognose, de prognose van de vervangingsvraag en de prognose van de toekomstige instroom van nieuwkomers op de arbeidsmarkt worden besproken. Ten slotte wordt een toelichting gegeven op de totstandkoming van de samenvattende indicatoren van aan de ene kant de arbeidsmarktperspectieven per opleidingstype (incl. bespreking van baanopeningen), en aan de andere kant de verwachte knelpunten in de personeelsvoorziening per opleidingstype en per beroepsgroep. 


\subsection{Methodiek uitbreidingsvraag}

Op basis van het Athena-model (CPB, 1990) maakt het CPB prognoses van de werkgelegenheidsontwikkeling per bedrijfstak. ${ }^{5}$ Deze werkgelegenheidsprognoses vormen het startpunt van de prognoses van de uitbreidingsvraag naar beroepsgroep en opleidingstype. De prognoses van de uitbreidingsvraag, maar ook de vervangingsvraag (zie hieronder) zijn deels gebaseerd op een scenario-analyse van het Centraal Planbureau (CPB, 2004 en 2005). De scenario's van het CPB hebben betrekking op de lange termijn (tot 2020 en 2040). Voor de prognoses wordt uitgegaan van één van de twee middenscenario's van het CPB, te weten 'Transatlantic Market' (TM), dat gegeven de recente ontwikkelingen op het moment van het samenstellen van de prognoses het meest realistisch werd geacht. Behalve het bij de prognoses gebruikte TM-middenscenario heeft het Centraal Planbureau nog drie overige lange termijnscenario's opgesteld. In ROA (2005) worden de scenario's in het kort besproken.

In afwijking van deze langetermijnramingen is voor de bedrijfssectorprognoses van de uitbreidingsvraag voor 2005 en 2006 gebruik gemaakt van het Centraal Economisch Plan 2005 (CEP) van het CPB (2005a). Door het gebruik van deze kortetermijnprognoses worden de gehanteerde langetermijnramingen gecorrigeerd met de meer recente inzichten in de groeiverwachtingen van het CEP. Verder is bij het bepalen van de bedrijfssectorprognoses van de uitbreidingsvraag tot 2010 verondersteld dat de sectorale werkgelegenheid op de lange termijn (in 2020) uitkomt op het niveau dat volgens het TM-scenario wordt bereikt.

Omdat het CPB de kortetermijnprognoses niet meer zoals voorheen volledig differentieert naar alle beschikbare sectoren, is tevens gebruik gemaakt van de verdere differentiatie van de kortetermijnprognoses van het CPB door het EIM (zie EIM, 2005). Alle prognoses van zowel het CPB als het EIM zijn te downloaden van de respectievelijke websites. De arbeidsvolume-prognoses van het CPB zijn met behulp van prognoses van de P/A-ratio's van het CPB en EIM omgerekend naar werkzame personen. De procentuele ontwikkelingen en de prognoses van het aantal werkenden in het informatiesysteem worden weergegeven ten opzichte van het geschatte aantal werkenden in het basisjaar $2004{ }^{6}$

5. Hieronder worden de benamingen 'bedrijfstakken' (CPB-term) en 'bedrijfssectoren' (zie ROA, 2002) door elkaar gebruikt.

6. Het aantal werkenden in 2004 is voor het berekenen van deze percentages geschat aan de hand van het beroepen- en opleidingenmodel voor de uitbreidingsvraag omdat op het moment van het samenstellen van de prognoses het aantal werkenden per beroepsgroep of opleidingstype uit de EBB 2004 nog niet beschikbaar was. 
Figuur 4.1

Overzicht van de totstandkoming van de prognoses van de uitbreidingsvraag naar beroep en opleiding

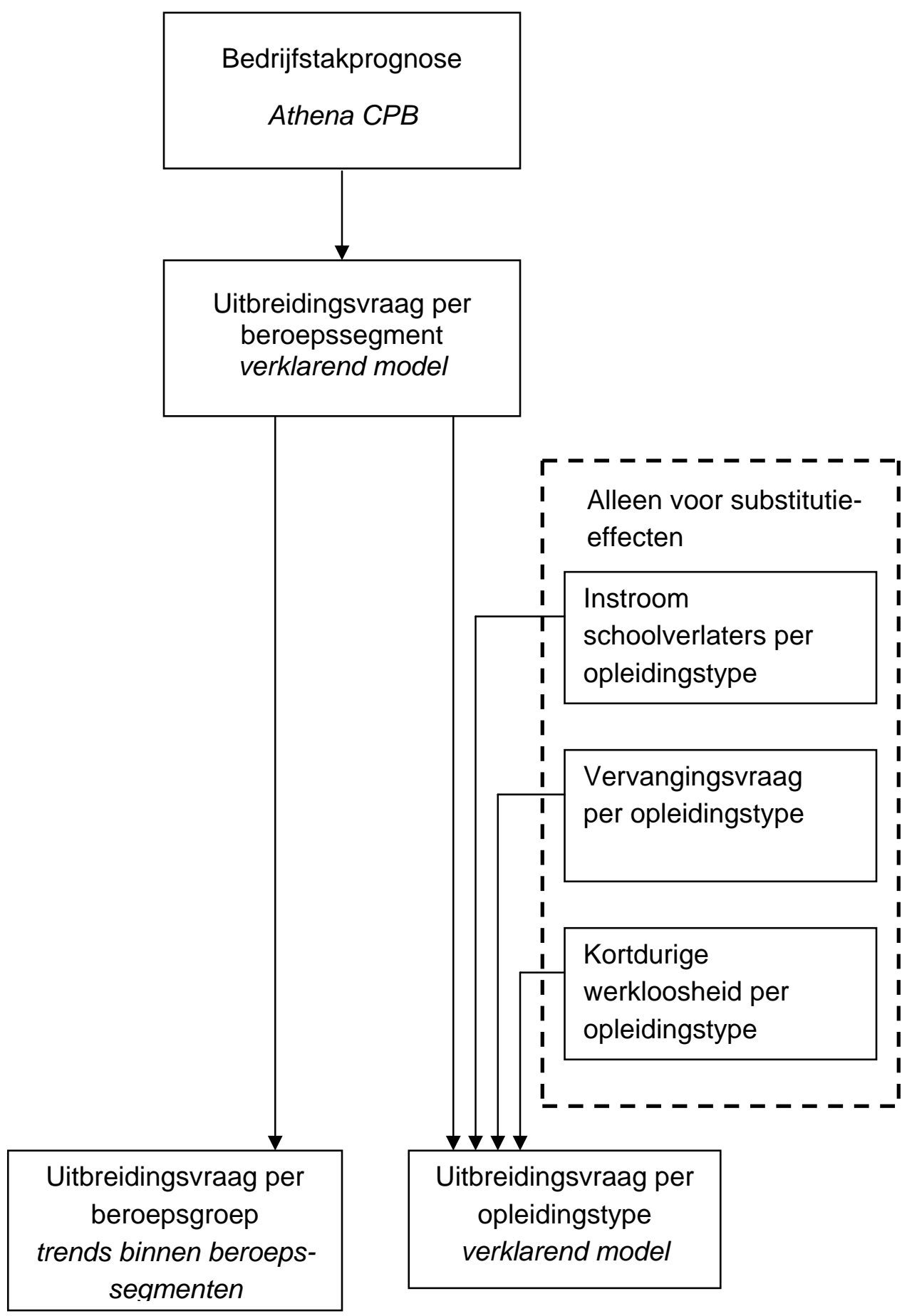

In aansluiting op de prognoses van de uitbreidingsvraag voor bedrijfssectoren worden door het ROA prognoses gemaakt van de verschuivingen in de beroepenstructuur binnen de onderscheiden bedrijfssectoren. Hierdoor kan er rekening gehouden worden met het feit dat binnen een bedrijfssector bepaalde beroepsgroepen zich sneller ontwikkelen dan andere. 
Voorts zijn er in het zogenaamde beroepenmodel van de uitbreidingsvraag, naast de trend van de werkgelegenheid, verschillende verklarende variabelen gebruikt om de prognoses van de uitbreidingsvraag naar beroep samen te stellen.

In figuur 4.1 staat aangegeven hoe de prognoses van de werkgelegenheidsontwikkeling voor beroepen en opleidingen tot stand komen. Vanuit de bedrijfssectorprognoses wordt een prognose opgesteld voor beroepssegmenten. Vervolgens vindt er vanuit de werkgelegenheidsprognoses per beroepssegment een verdere uitsplitsing plaats naar de beroepsgroepen. De beroepenindeling is gebaseerd op de Standaard Beroepen Classificatie uit 1992 (SBC '92) van het CBS (1993). De beroepssegmenten zijn gebaseerd op de indeling op 2-digit-niveau; de beroepsgroepen op de indeling op 3-digit-niveau. Er worden in totaal 43 beroepssegmenten en 127 beroepsgroepen onderscheiden. ${ }^{7}$

De prognoses van de werkgelegenheidsontwikkelingen per beroepssegment vormen de basis voor de prognoses van de uitbreidingsvraag per opleidingstype. In het opleidingenmodel vindt een confrontatie plaats tussen vraag en aanbod, waardoor ook de invloeden op de vraag die veroorzaakt worden door overschotten of tekorten in aanverwante studierichtingen in het model konden worden opgenomen. Hiervoor zijn de prognoses van de arbeidsmarktinstroom van schoolverlaters en de vervangingsvraag en de informatie over de kortdurige werkloosheid per opleidingstype aan het begin van de prognoseperiode noodzakelijke invoergegevens voor het model.

\section{Het beroepenmodel}

In het beroepenmodel wordt de voorspelde werkgelegenheidsontwikkeling per bedrijfstak omgezet naar de werkgelegenheidsontwikkeling per beroepssegment en beroepsgroep. Hierbij wordt de veronderstelling gemaakt dat de werkgelegenheid per beroepsgroep volledig door de vraagzijde van de markt bepaald wordt. De ontwikkelingen in de vraag per beroepsgroep worden bepaald door de werkgelegenheidsverschuivingen tussen bedrijfssectoren en de veranderingen in de beroepenstructuur van de werkgelegenheid per bedrijfssector.

De uitbreidingsvraag naar beroep is geschat met EBB-data van 1988 tot en met 2003. Het gaat bij deze werkgelegenheidscijfers om werkzame personen die voor minstens 12 uren per week werk hebben. In de EBB-matrices beroepssegment $x$ bedrijfssector zijn de aantallen beneden de door het CBS vereiste ondergrens gelijkgesteld aan 0 . Hierdoor verdwijnen in iedere bedrijfssector een aantal kleinere beroepssegmenten. Beroepssegmenten die voor één of meerdere jaren niet voorkomen in de tijdreeks zijn weggelaten. In totaal is de werkgelegenheidsontwikkeling geschat voor 195 combinaties van beroepssegmenten en bedrijfssectoren.

7. Zie de 2-digit- en 3-digit-codes en de bijbehorende benamingen in tabel 6 en 7 van de $R O A$ classificatiegids (ROA, 2002). 
Het CBS is vanaf 1994 over gegaan op een nieuwe bedrijfssectorindeling. Om toch de EBB gegevens voor de periode 1988 tot en met 1993 te kunnen gebruiken is een schatting gemaakt van aantallen werkenden per bedrijfssector volgens de nieuwe indeling. Dit was mogelijk omdat in 1994 zowel de oude als de nieuwe classificatie gehanteerd zijn. De verhoudingen van de aantallen werkenden per beroepssegment per bedrijfssector volgens de oude en nieuwe indeling in dat jaar zijn dus bekend. Voorts heeft het CBS vanaf 1996 een nieuwe reeks van EBB-bestanden met vergelijkbare classificaties en dataverzameling samengesteld. Vanwege de bovenstaande twee aanpassingen is gekeken naar breuken in de tijdreeksen voor de jaren tussen 1994 en 1996. Dit heeft ertoe geleid dat voor 19 van de 195 combinaties van sector en beroep dummy-variabelen zijn opgenomen in de schattingsvergelijkingen.

De beroepenstructuur binnen bedrijfssectoren wordt geschat aan de hand van een nieuw model van Cörvers en Dupuy (2006). ${ }^{8}$ In dit model spelen, behalve de tijdtrend, vier factoren een rol bij de verklaring van de veranderingen in de vraag naar beroepen binnen bedrijfssectoren. De beroepenstructuur binnen bedrijfssectoren wordt bepaald door het productieniveau ('non-homothetic production function') per bedrijfssector, de kapitaalintensiteit per bedrijfssector ('capital-skill complementarity'), het gebruik van nieuwe meer kennisintensieve technologieën ('skill biased technological change') in elke bedrijfssector, en de relatieve lonen op de verschillende arbeidsmarktsegmenten. Om het model te schatten zijn voor de 13 verschillende bedrijfssectoren data verzameld over de toegevoegde waarde, de investeringen in kapitaal en de investeringen in Research and Development (R\&D) tussen 1988 en 2003. ${ }^{9}$ De benodigde data zijn ontleend aan de zogenaamde 'Lange Reeksen' van het CPB. Deze reeksen zijn gebaseerd op de Nationale Rekeningen van het CBS, en worden door het CPB gebruikt als data-input voor de schattingen van de vergelijkingen in het Athena-model. Alleen de R\&D-gegevens zijn direct afkomstig van het CBS (via Statline), en zijn gebaseerd op de R\&D- en innovatie-enquêtes van het CBS onder bedrijven, research-instellingen en universiteiten. De investeringen in kapitaal en R\&D zijn omgerekend naar voorraadgrootheden volgens de algemeen gebruikte Perpetual Inventory Method (PIM). De gehanteerde afschrijvingspercentages zijn 8\% voor kapitaal en 15\% voor R\&D.

In de eerste stap van de schattingsprocedure is getoetst of de verschillende tijdreeksen al dan niet stationair zijn, dat wil zeggen er is gekeken naar de significantie van een stochastische of deterministische trend in de werkgelegenheidsontwikkeling van de beroepssegmenten per bedrijfssector en de bovengenoemde vier verklarende variabelen. De 'unit root'-testen wijzen uit dat er bijna altijd sprake is van een stochastische trend. Tevens is er in meer dan driekwart van de tijdreeksen een significante deterministische trend. Uit de

8. Het oude model was gebaseerd op Borghans en Heijke (1994). Zij gebruikten een randomcoëfficiënten-model met verklarende variabelen uit het Athena-model. Zij deden de aanbeveling om nader onderzoek te verrichten naar variabelen waarmee de werkgelegenheidsontwikkeling naar beroep beter verklaard en voorspeld kan worden.

9. Een vierde verklarende variabele, de loonsom per sector, bleek sterk gecorreleerd te zijn aan de toegevoegde waarde en is daarom niet meegenomen in het definitieve schattingsmodel. 
resultaten van de empirische toetsing kan geconcludeerd worden dat alle tijdreeksen nonstationair en geïntegreerd van de eerste orde zijn. Derhalve wordt er getoetst of er sprake is van coïntegratie tussen de werkgelegenheidsaandelen van beroepssegmenten per bedrijfssector en de verklarende sectorvariabelen.

In de test op coïntegratie wordt gekeken naar de afwijking van het aandeel van de werkgelegenheid van een beroepssegment in een bedrijfssector van het geschatte langetermijnverband (zie de 'error correction' term in vgl. 4.1). Het blijkt dat de residuen stationair zijn voor meer dan driekwart van de combinaties van beroepssegment en bedrijfssector. Voor de werkgelegenheidsaandelen van beroepssegment $j$ in bedrijfssector $i$, weergegeven door $l_{i j, t}$, worden daarom aan de hand van de betreffende tijdreeksen van 1988-2003 $(t)$ de volgende vergelijkingen geschat volgens de 'error correction' specificatie zoals voorgesteld door Engle en Granger (1987):

$$
\Delta l_{i j, t}=\alpha_{i j}+\sum_{k} \lambda_{k i j} \Delta x_{k i, t}+\gamma_{i j} \sum_{k}\left(l_{i j, t-1}-\beta_{k i j} x_{k i, t-1}\right)+\varepsilon_{i j, t}^{*}
$$

waarbij $x_{k i, t}$ de verklarende variabelen $k$ per bedrijfssector $i$ representeren, en $\varepsilon_{i j, t}^{*}$ is een storingsterm. $\alpha_{i j}$ en $\lambda_{k i j}$ zijn de parameters voor respectievelijk de constante en de $k$ verklarende variabelen ( $k=3$ ). Bovendien geven de parameters $\gamma_{i j}$ en $\beta_{k i j}$ de effecten weer van de afwijkingen van het langetermijnevenwicht (de 'error correction') en de verklarende variabelen $k$ op de werkgelegenheidsaandelen van beroepssegment $j$ in bedrijfssector $i$. Het 'error correctie' mechanisme is in ongeveer 95\% van de combinaties van bedrijfssectoren en beroepssegmenten statistisch significant. In afwijking van de prognosemethodiek van twee jaar geleden (zie Cörvers et al., 2004) is de bovenstaande specificatie aangepast door in de storingstermen ook rekening te houden met intertemporele correlaties tussen combinaties van bedrijfssectoren en beroepssegmenten. Deze techniek staat bekend als de zogenaamde Dynamic OLS (Mark et al., 2003). Bovendien zijn de verschillende schattingsvergelijkingen 'gepoold', waarbij 'fixed effects' voor de sectoren en de beroepssegmenten zijn opgenomen. Dit laatste verlaagt de variantie van de geschatte parameters doordat het aantal vrijheidsgraden aanzienlijk toeneemt (zie verder Cörvers en Dupuy, 2006).

De prognoses voor de drie verklarende variabelen in het beroepenmodel zijn op verschillende manieren tot stand gekomen. Voor de toegevoegde waarde zijn zowel de korte- als de langetermijnprognoses tot 2010 op eenzelfde manier bepaald als voor de sectorale werkgelegenheid. Wat betreft de investeringen in kapitaal is voor 2005 en 2006 gebruik gemaakt van de kortetermijnprognoses van het CPB (2005a) en het EIM (2005). Omdat langetermijnramingen van de investeringen in kapitaal voor de jaren na 2006 niet direct beschikbaar waren, is voor deze jaren 'double exponential smoothing' toegepast. Voor de investeringen in R\&D waren geen prognoses beschikbaar. Deze zijn gebaseerd op een extrapolatie met 'double exponential smoothing' van de tijdreeksen van het CBS. 
De aggregatie over dezelfde beroepssegmenten binnen de verschillende bedrijfssectoren resulteert in de prognoses van de uitbreidingsvraag per beroepssegment. Vervolgens zijn de prognoses per beroepssegment verbijzonderd naar beroepsgroepen. Hierbij is gebruik gemaakt van het random-coëfficiënten-model. De werkgelegenheidsgroei per beroepsgroep wordt daarbij geschat als afwijking van de totale groei van het beroepssegment waar de betreffende beroepsgroep onder valt. Om stabiele parameterschattingen te krijgen zonder daarbij de specificiteit van de afzonderlijke beroepen aan te tasten is gebruik gemaakt van een random-coëfficiënten-model. ${ }^{10}$ In dit random-coëfficiënten-model worden de parameterwaarden bepaald als een gewogen gemiddelde van aan de ene kant een gemiddelde parameterwaarde over de beroepsgroepen waarover gepoold wordt, en aan de andere kant schattingen voor de afzonderlijke beroepsgroepen. Het gewicht wordt bepaald door de nauwkeurigheid van beide onderdelen. Als er veel variatie is tussen de verschillende beroepsgroepen binnen een beroepssegment is een gepoolde schatting relatief onnauwkeurig en komt er meer gewicht op de afzonderlijke schattingen te liggen. Als deze afzonderlijke schattingen echter een hoge standaardfout hebben wordt hun gewicht verlaagd. Op deze wijze ontstaat er een optimale combinatie van de informatie van de gepoolde gegevens en de afzonderlijke schattingen.

$$
\Delta l_{t}^{g}=\Delta l_{t}^{j}+\beta_{0}^{g}+\beta_{1}^{g}\left(\Delta l_{t-1}^{g}-\Delta l_{t-1}^{j}\right)+\varepsilon_{t}
$$

waarbij:

$l_{t}^{g}=$ logaritme van het aantal werkzame personen in beroepsgroep $g$ op tijdstip $t$;

$l_{t}^{j}=$ logaritme van het totaal aantal werkzame personen in beroepssegment $j$ waartoe beroepsgroep $g$ wordt gerekend op tijdstip $t$.

Bij de schattingen van het random-coëfficiënten-model is gebruik gemaakt van EBBtijdreeksen van het aantal werkenden per beroepsgroep voor de jaren 1996-2003. Voor sommige beroepssegmenten en beroepsgroepen bleek de variantie in de tijdreeks van het aantal werkenden dermate groot dat de schattingen ad hoc zijn aangepast. Een dergelijke grote variantie gaat meestal samen met een klein aantal werkenden in de EBB (bijv. de zweminstructeurs).

\section{Het opleidingenmodel}

Bij de prognoses die in 1993 werden opgesteld is voor het eerst expliciet een onderscheid gemaakt tussen de 'vraag' en de 'werkgelegenheid' per opleidingstype. Onder vraag wordt verstaan de hoeveelheid werk die wordt aangeboden als de verhoudingen op de arbeidsmarkt zich niet zouden wijzigen. Als er echter voor een bepaalde opleidingsrichting discrepanties ontstaan tussen de vraag- en aanbodontwikkeling, zullen er in de praktijk veelal aanpassingsprocessen ontstaan. Zo leidt een overschot aan de aanbodkant er mogelijk toe dat schoolverlaters banen krijgen waarin ze voorheen niet werkzaam waren. De

10. Borghans en Heijke (1994) geven een uitvoerige beschrijving van dit model. 
uiteindelijke hoeveelheid werk wordt aangeduid als werkgelegenheid. Er ontstaat derhalve een verschil tussen het ex ante vraagbegrip en de ex post werkgelegenheid.

Om de te verwachten spanning tussen vraag en aanbod in kaart te brengen is de ex ante vraag het meest geschikt. De aanpassingen die achteraf plaatsvinden zijn immers al een uiting van deze spanningen tussen vraag en aanbod. In de data wordt echter de ex post vraag waargenomen. Door in het opleidingenmodel de historische vraag te baseren op deze feitelijke werkgelegenheid worden mogelijk vraag- en aanbodelementen samengenomen. Wanneer in het verleden een toename in de werkgelegenheid het gevolg was van een vergroot aanbod kan dit geïnterpreteerd worden als een toename van de ex ante vraag, waardoor de spanning tussen vraag en aanbod onderschat zal worden. Om deze verwarring tussen vraag- en aanbodelementen te voorkomen is door Borghans en Heijke (1996) een model ontwikkeld waarin het onderscheid tussen ex ante en ex post vraag naar arbeid expliciet is opgenomen. In dit model wordt, om deze twee afzonderlijke categorieën te kunnen identificeren, rekening gehouden met de onderlinge substitutie tussen opleidingstypen. In Borghans (1996) is dit model verder uitgewerkt.

Figuur 4.2

De opbouw van de vraag naar arbeid per opleidingstype

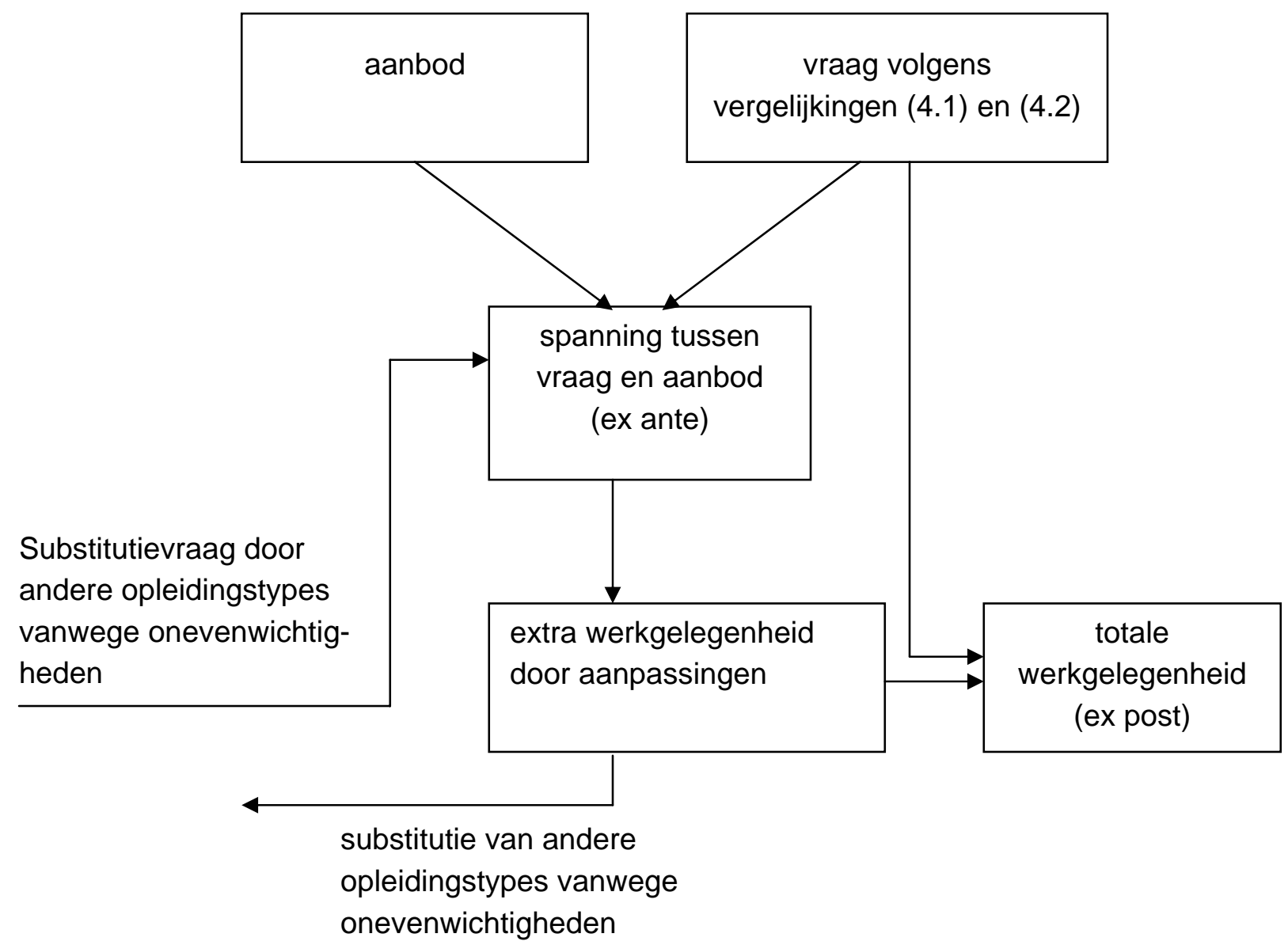


In figuur 4.2 wordt de opbouw van het model getoond. De ex ante vraag per opleidingstype (o) per beroepssegment $b$ wordt bepaald door de verdeling van de opleidingstypen in dit beroepssegment in het laatste observatiejaar. Op basis van Borghans (1996) en Dupuy (2006) is geschat in welke mate de vraag naar een bepaald opleidingstype toe- of afneemt als gevolg van trendmatige verschuivingen. Deze veranderingen in de vraag weerspiegelen de up- en downgradingsprocessen in de werkgelegenheidsstructuur. In Dupuy (2006) wordt een vergelijking gemaakt tussen de 'skill-upgrading' voor zes opleidingsniveaus in twee periodes, namelijk 1979-1992 en 1996-2003, waarbij duidelijk blijkt dat het tempo van de upgrading is afgenomen over de tijd. De trendmatige verschuivingen in de opleidingsstructuur die zijn gebruikt voor de prognoses tot 2010 zijn echter gebaseerd op verschuivingen in de werkgelegenheidsstructuur van 27 opleidingscategorieën (zie ROA, 2002) in de periode tussen 1996 en 2003. Een verdere differentiatie naar de 102 opleidingstypen bleek voor enkele opleidingstypen tot uitschieters te leiden. Bij aggregatie van de 27 opleidingscategorieën of de 102 opleidingstypen naar zes opleidingsniveaus komen de resultaten echter goed overeen met de directe schattingen van de upgrading naar de zes opleidingsniveaus (zie voor de directe schattingen Dupuy, 2006).

Ten slotte worden deze trendmatige ontwikkelingen gecorrigeerd voor een toe- of afname in de werkgelegenheid die het gevolg is van 'overschotten' of 'tekorten' aan mensen met een bepaalde opleidingsachtergrond. Als de vraag groter is dan het aanbod voor een bepaald opleidingstype zal immers de uiteindelijke werkgelegenheid zoals die wordt waargenomen kleiner zijn dan de oorspronkelijke vraag. Omgekeerd zal bij een aanbodoverschot de uiteindelijke werkgelegenheid juist groter worden vanwege verdringingsprocessen. Borghans en Willems (1998) gaan in op deze relatie tussen vraag en werkgelegenheid. Als het aanbod van een opleidingstype groter is dan de vraag, zal volgens dit model de arbeidsmarktpositie van het opleidingstype verslechteren. De nieuwkomers op de arbeidsmarkt zullen daardoor moeten uitwijken naar andere minder aantrekkelijke banen. Deze uitwijk naar andere banen is geschat op basis van de methode in Borghans (1996). Omdat de totale vraag per beroepssegment verondersteld wordt constant te zijn, betekent de instroom van het ene opleidingstype automatisch de verdringing van andere opleidingstypen. Hier wordt verondersteld dat deze uitstroom proportioneel is aan de opleidingsstructuur van dit beroepssegment. Deze verdringing betekent voor de betreffende opleidingstypes echter een vergroting van de discrepantie tussen vraag en aanbod. Door enkele malen een iteratie uit te voeren wordt een evenwichtssituatie gevonden die de ex ante vraag met substitutie aangeeft.

Deze uitbreidingsvraag met substitutie geeft aan hoe groot de vraag naar schoolverlaters met een bepaalde opleidingsachtergrond is, als er geen rekening wordt gehouden met de mate waarin dit opleidingstype zich aanpast aan de arbeidsmarktsituatie (de 'actieve substitutie'), maar waarbij wel rekening is gehouden met de vraagtoename, als gevolg van een vraagoverschot bij een andere verwante opleiding, of een vraagafname vanwege de verdringing door andere opleidingstypen (de 'passieve substitutie'). De reden waarom er geen rekening wordt gehouden met de 'actieve' substitutie is dat deze aanpassingen - in het geval van een aanbodoverschot - op zichzelf reeds een verslechtering zullen betekenen. Door de werkgelegenheid die door het aanpassingsproces op de arbeidsmarkt wordt 
verkregen in mindering te brengen op het aanbodoverschot zou een verslechterend perspectief onderschat worden. Het verlies aan werkgelegenheid door de aanpassingen van andere opleidingstypen betekent echter een verslechtering van de werkgelegenheid, zodat deze component wel moet worden meegenomen in de ex ante vraag (zie De Grip, Borghans en Smits, 1998 en Cörvers en Heijke, 2004).

Ook bij het opleidingenmodel hebben enkele aanpassingen van het basismodel plaatsgevonden. Bij de hogere onderwijskundige beroepen, de middelbare en hogere medische en paramedische beroepen en de hogere theologische beroepen is uitgesloten dat er substitutie plaatsvindt, omdat er in de praktijk scherpe afgrenzingen zijn tussen de vakgebieden van de beroepsgroepen die binnen deze beroepssegmenten worden onderscheiden.

\subsection{Methodiek vervangingsvraag}

Naast de uitbreidingsvraag is ook de vervangingsvraag een belangrijke component van het totaal aantal baanopeningen voor de nieuwkomers op de arbeidsmarkt. Met de vervangingsvraag wordt de vraag naar nieuwkomers bedoeld die ontstaat als gevolg van het verloop vanwege pensionering, VUT, arbeidsongeschiktheid, (tijdelijke) uittreding van met name gehuwde vrouwen, beroepsmobiliteit e.d. (zie ook Willems en De Grip, 1993). Bij een toename van de werkgelegenheid is de vervangingsvraag gelijk aan het aantal werkenden dat hun baan in een bepaalde periode verlaat. De opengevallen arbeidsplaatsen zullen immers eerst moeten worden opgevuld voordat er sprake kan zijn van werkgelegenheidsgroei. Echter, ook bij een dalende werkgelegenheid kan de vraag naar nieuwkomers, uitsluitend als gevolg van de vervangingsvraag, nog aanzienlijk zijn. Het blijkt dat werkgevers voor het realiseren van een afname van het personeelsbestand bij een teruglopende vraag naar arbeid aan de 'exit'-optie van ouderen de voorkeur geven boven de 'no entry'-optie van bijvoorbeeld schoolverlaters (zie Willems, Borghans en De Grip, 1997). De vervangingsvraag is dan echter niet gelijk aan de uitstroom, maar alleen aan de uitstroom voor zover deze vervangen wordt. Dit impliceert dat bij een krimpende vraag de vervangingsvraag lager zal zijn dan de uitstroom van werkenden.

Overigens dient te worden beseft dat de vervangingsvraag gesommeerd over alle beroepsgroepen niet gelijk is aan de vervangingsvraag gesommeerd over alle opleidingstypen. De beroepsmobiliteit is namelijk wel van invloed op de vervangingsvraag per beroepsgroep, maar heeft geen effect op de vervangingsvraag per opleidingstype. Het veranderen van beroep heeft immers geen gevolgen voor de opleidingsstructuur van de werkgelegenheid. Daarentegen kan een werkende door het afronden van een vervolgopleiding in feite 'uitstromen' naar een ander opleidingstype. In dat geval is er sprake van een vervangingsvraag bij het opleidingstype waartoe de vooropleiding van deze werkende wordt gerekend.

Voor het bepalen van de vervangingsvraag is een model ontwikkeld dat nauw aansluit bij de in demografische analyses vaker gebruikte cohort componenten methode. De cohortcomponenten-methode baseert de berekening van de zogenaamde 'cohort change rates' op 
het aantal personen in hetzelfde geboortecohort die werkzaam zijn in twee verschillende tijdsperioden. Een cohort is hier een combinatie van geslacht en vijfjaars-leeftijdsklasse. ${ }^{11}$ Deze methode maakt gebruik van standcijfers over de geslachts- en leeftijdsopbouw van de beroepsbeoefenaren over een aantal jaren. ${ }^{12}$ Door van jaar op jaar een vergelijking te maken van de demografische opbouw in een bepaalde beroepsgroep of een bepaald opleidingstype, wordt een beeld verkregen van de (netto) in- of uitstroom voor de desbetreffende beroepsgroep of het desbetreffende opleidingstype. Op dit model zal hier kort worden ingegaan (zie voor een verdere toelichting Willems, 1999).

Kernpunt bij de methodiek voor de bepaling van de vervangingsvraag is de afleiding van de netto in- en uitstroomratio's. Deze ratio's weerspiegelen de relatieve toe- of afname van het aantal werkenden in een beroepsgroep ${ }^{13}$ van een bepaald geboortecohort gedurende een bepaalde periode. In symbolen kunnen de 'cohort change rates' worden weergegeven als: ${ }^{14}$

$$
\dot{F}_{b x}^{t-1}=\frac{W_{b x+1}^{t}-W_{b x}^{t-1}}{W_{b x}^{t-1}}
$$

waarbij:

$\dot{F}_{b x}^{t-1}=$ netto in- of uitstroomratio van de werkenden in beroep $b$ met leeftijdklasse $x$ op tijdstip $t$ - 1 , gedurende de periode $(t-1, t)$;

$W_{b x}^{t}=$ aantal werkenden in beroep $b$ in leeftijdsklasse $x$ op tijdstip $t$.

Indien $\dot{F}_{b x}^{t-1}>0$ dan is er sprake van netto instroom voor leeftijdscohort $x$ van beroep $b$ en als $\dot{F}_{b x}^{t-1}<0$ dan is er sprake van netto uitstroom. Er wordt dus met behulp van de cohort change rate de netto uitstroom, het saldo van uit- en instroom, in het verleden per beroepsgroep bepaald. De vervangingsvraag die wordt opgevuld door (her-)intredende personen van hetzelfde cohort (combinatie van geslacht én leeftijdsklasse) kan niet uit de beschikbare data worden afgeleid en wordt derhalve ook niet expliciet bij de bepaling van de vervangingsvraag meegenomen. Dit houdt in dat wordt aangenomen dat een meer dan normaal (op basis van het verleden) geacht aantal herintreders in de wachtrij voor nieuwe banen achteraan moet sluiten bij de nieuw op de markt komende schoolverlaters (zie ook Borghans, De Grip en Willems, 1995).

11. Zie voor een verdere toelichting Shryock en Siegel (1980).

12. Bij het opstellen van de prognoses voor de periode tot 2010 is gebruik gemaakt van naar geslacht en leeftijdsklasse verbijzonderde gegevens over het aantal werkenden per beroepsgroep en opleidingstype voor de periode 1996-2003.

13. De methodiek is hier uitgewerkt voor de vervangingsvraag per beroepsgroep. De vervangingsvraag per opleidingstype wordt op vrijwel analoge wijze bepaald.

14. Daarnaast zijn de ratio's verbijzonderd naar geslacht. Omwille van de overzichtelijkheid van de notatie is de geslachtsindex weggelaten. 
Vervolgens wordt er gebruik gemaakt van een 'fixed-effect-model', waarbij de netto in- of uitstroomratio's worden verklaard op basis van de beroepsspecifieke afwijkingen per geslacht en leeftijdsklasse van de gemiddelde in- of uitstroompatronen uit de totale werkzame bevolking. ${ }^{15}$ Dit houdt in dat als een geschatte uitstroomcoëfficiënt voor een bepaalde beroepsklasse of opleidingstype sterk afwijkt, de geschatte parameter die de afwijking van het gemiddelde aangeeft waarschijnlijk significant zal zijn. Een dergelijke aanpak garandeert dat de som van de netto stromen over de beroepen overeenkomt met de totale netto in- of uitstroom.

In formulevorm:

$$
\dot{F}_{b}=\dot{F}+\sum_{x} \beta_{b x} D_{x}
$$

waarbij:

$\dot{F}_{b}=$ vector van netto in- of uitstroomratio's voor beroep $b$, met waarnemingen per geslacht, leeftijdsklasse en jaar;

$\dot{F}=$ idem, maar dan voor de gehele werkzame bevolking;

$D_{x}=$ matrix met dummy-variabelen; waarden zijn gelijk aan 1 voor cohort $x$ en 0 elders;

$\beta_{b x}=$ random parameters.

Vergelijking (4.4) laat zien dat de stromen van de arbeidsmarkt voor een bepaalde beroepsgroep per leeftijdscohort gelijk zijn aan de gemiddelde stroom van de arbeidsmarkt van dat leeftijdscohort, afgezien van beroepsspecifieke afwijkingen die kunnen verschillen per leeftijdsklasse.

Onder de veronderstelling dat de niet-werkzame beroepsbevolking in de prognoseperiode gelijk blijft (de zgn. conjunctuurcorrectie, zie hieronder), wordt een voorspelling gekregen van de toekomstige uitstroom uit de werkzame bevolking. De schattingsresultaten van vergelijking (4.4) dienen als basis voor een prognose van de toekomstige netto in- en uitstroomratio's. Deze uitstroomcoëfficiënten worden met behulp van de door het CPB opgestelde prognoses van de (bruto) participatiegraad in het eerder genoemde TM-scenario (CPB, 2004a) geprojecteerd op de populatie in het basisjaar om een prognose te kunnen maken van de uitstroom in de komende jaren. ${ }^{16}$ Deze prognose is dus voor alle cohorten van de beroepsbevolking gecorrigeerd voor de verwachte verandering in de arbeids-

15. In tegenstelling tot voorgaande jaren is nu het 'fixed-effect-model' gebruikt in plaats van het 'random-coëfficiënten-model'. De reden hiervoor is gelegen in een grotere stabiliteit van de geschatte parameters in het 'fixed-effect-model'.

16. Zie Cörvers, Kriechel en Montizaan (2006) voor een scenario-analyse van de vervangingsvraag. Uit deze studie blijkt tevens de beperkte gevoeligheid voor afwijkingen van de toekomstige ontwikkeling van de participatiegraad ten opzichte van het gehanteerde TM-scenario ('Transatlantic Market'). 
participatie. Naast deze participatiecorrectie vindt ook een vergelijkbare correctie plaats voor de conjuncturele situatie in de analyseperiode. Beide correctiefactoren zijn voor alle beroepsklassen en opleidingstypen gelijk. Figuur 4.3 bevat een samenvattend overzicht van de methodiek van het opstellen van de prognoses voor de vervangingsvraag. ${ }^{17}$

\section{Figuur 4.3}

Samenvattend overzicht van de methodiek van de vervangingsvraag (excl. specifieke aanpassingen en 'doorleerderscomponent')

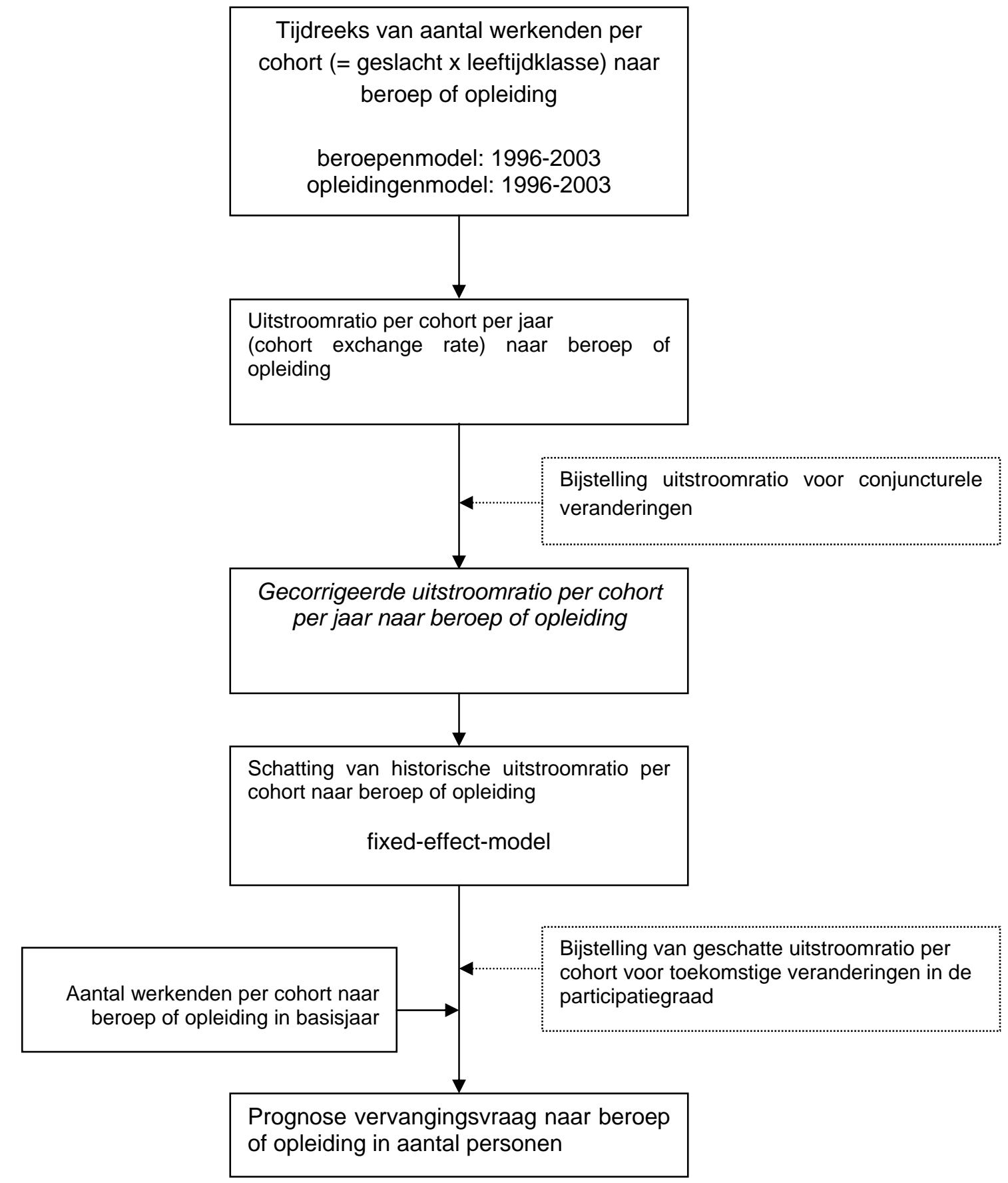

17. Zie Shah en Burke (2001) voor een vergelijking van de methodiek van de vervangingsvraag naar beroep tussen Australië, de Verenigde Staten en Nederland. 
De correctie voor de conjuncturele situatie is gelijk aan het verschil tussen de verandering in het totale aantal werkende personen en de verandering in de beroepsbevolking in de historische periode. Deze correctie compenseert de uitstroom van werkenden die werkloos zijn geraakt door conjuncturele fluctuaties in het werkgelegenheidsniveau. De correctie voor de verandering in de participatiegraad is het verschil tussen de groei in de beroepsbevolking in de historische periode en de voorspelperiode.

Als de correcties voor de conjunctuur en de participatiegraad gecombineerd worden dan levert dit de voorspelde toekomstige uitstroomratio per cohort op:

$$
\begin{aligned}
\dot{W}_{b x}^{t, m} & =\dot{W}_{b x}^{t, n}-\dot{W} P_{x}^{t, n}+\dot{L} F_{x}^{t, n}+\dot{L} F_{x}^{t, m}-\dot{L} F_{x}^{t, n} \\
& =\dot{W}_{b x}^{t, n}-\dot{W} P_{x}^{t, n}+\dot{L} F_{x}^{t, m}
\end{aligned}
$$

waarbij:

$\dot{W}_{b x}^{t, m}=$ de verwachte gemiddelde jaarlijkse netto in- of uitstroomratio van werkenden in beroep $b$, in cohort $x$ op tijdstip $t$ gedurende de voorspelperiode $(t, t+m)$;

$\dot{W}_{b x}^{t, n}=$ de verwachte gemiddelde jaarlijkse netto in- of uitstroomratio van werkenden in beroep $b$, in cohort $x$ op tijdstip $t-n$ gedurende de periode $(t-n, t)$;

$\dot{W} P_{x}^{t, n}=$ de gemiddelde jaarlijkse groeiratio van het totale aantal werkende personen in cohort $x$ op tijdstip $t$ - $n$ gedurende de periode $(t-n, t)$;

$\dot{L} F_{x}^{t, n}=$ de gemiddelde jaarlijkse groeiratio van de beroepsbevolking in cohort $x$ op tijdstip $t$ $n$ gedurende de periode $(t-n, t)$;

$\dot{L} F_{x}^{t, m}=$ de verwachte gemiddelde jaarlijkse groeiratio van de beroepsbevolking in cohort $x$ op tijdstip t gedurende de voorspelperiode $(t, t+m)$.

De toekomstige vervangingsvraag wordt in feite op dezelfde manier bepaald als de vervangingsvraag in de historische periode. Dit houdt in dat voor beroepsgroepen met een verwachte stijging van de werkgelegenheid de vervangingsvraag gelijk is aan de netto uitstroom. De ontwikkeling van de werkgelegenheid per beroepsgroep wordt per geslacht afzonderlijk bekeken. Voor beroepsgroepen waarbij een daling van de werkgelegenheid in een bepaald jaar voor één van beide geslachten wordt verwacht, wordt de vervangingsvraag voor het betreffende jaar en geslacht op nul gesteld.

Vervangingsbehoefte vanwege 'doorleerders'

Om de vervangingsbehoefte per opleidingstype te bepalen, is dit jaar naast de vervangingsbehoefte die uit het beschreven model volgt, een tweede component onderscheiden. Het gaat hier om de vervangingsbehoefte die voortvloeit uit het feit dat sommige werkenden vervolgopleidingen volgen en daarmee een vervangingsbehoefte creëren voor de banen met de opleidingskwalificatie die ze oorspronkelijk hadden. Deze zogenaamde 'doorleerders' zijn dus werkenden die van opleiding veranderen en daarmee impliciet een vervangingsvraag genereren bij hun herkomstopleiding. 
Op dit punt moeten de prognoses van de instroom van schoolverlaters en de vervangingsvraag naar opleidingstype vanzelfsprekend goed op elkaar worden afgestemd. Een probleem dat zich hierbij voordoet is dat bij de leeftijdsgroepen 20-24 jaar, 25-29 jaar en 3034 jaar de verwachte vervangingsvraag vanwege de 'uitstroom' van doorlerenden naar een hoger opleidingstype op basis van de bovenstaande methodiek niet goed wordt gemeten, omdat er in deze leeftijdsgroepen nog een aanzienlijke instroom plaatsvindt, waartegen de uitstroomcijfers wegvallen. Daarom baseren we ons voor deze leeftijdsgroep liever op de EBB-cijfers van degenen die door het afronden van een post-initiële opleiding een andere opleidingsachtergrond krijgen. Deze doorleerders veranderen van opleiding en laten een vervangingsvraag achter bij hun herkomstopleiding. De cijfers van de doorleerders naar herkomst vormen een betere afspiegeling voor de (vervangings)vraag in de jonge leeftijdsgroepen, dan de feitelijke uitstroomcijfers.

\subsection{Methodiek instroom van schoolverlaters op de arbeidsmarkt}

De prognoses van de instroom op de arbeidsmarkt zijn gebaseerd op een verdeelmodel, dat een stapsgewijze modulaire opbouw heeft. Figuur 4.4 geeft een schematisch overzicht van deze opbouw. In het prognosemodel worden globaal gesproken twee stappen onderscheiden. In de eerste stap wordt de prognose opgesteld van de verwachte toekomstige uitstroom uit het regulier voltijdonderwijs. Niet voor alle schoolverlaters eindigt na het verlaten van het regulier voltijdonderwijs echter de schoolloopbaan. $\mathrm{Na}$ het verlaten van het voltijdonderwijs kan men immers nog doorstromen naar het deeltijdonderwijs, inclusief de beroepsbegeleidende leerweg (BBL, het voormalige leerlingwezen), het niet-reguliere voltijdonderwijs en de beroepsgerichte volwasseneneducatie. Als men daar een diploma behaald heeft en de gevolgde opleiding heeft een hoger niveau of een andere opleidingsrichting dan de genoten vooropleiding, dan moet de instroomprognose worden bijgesteld. Deze bijstelling vindt plaats in de tweede stap. 
Figuur 4.4

Globaal schema ter bepaling van de verwachte toekomstige instroom van schoolverlaters op de arbeidsmarkt naar ROA-opleidingstype

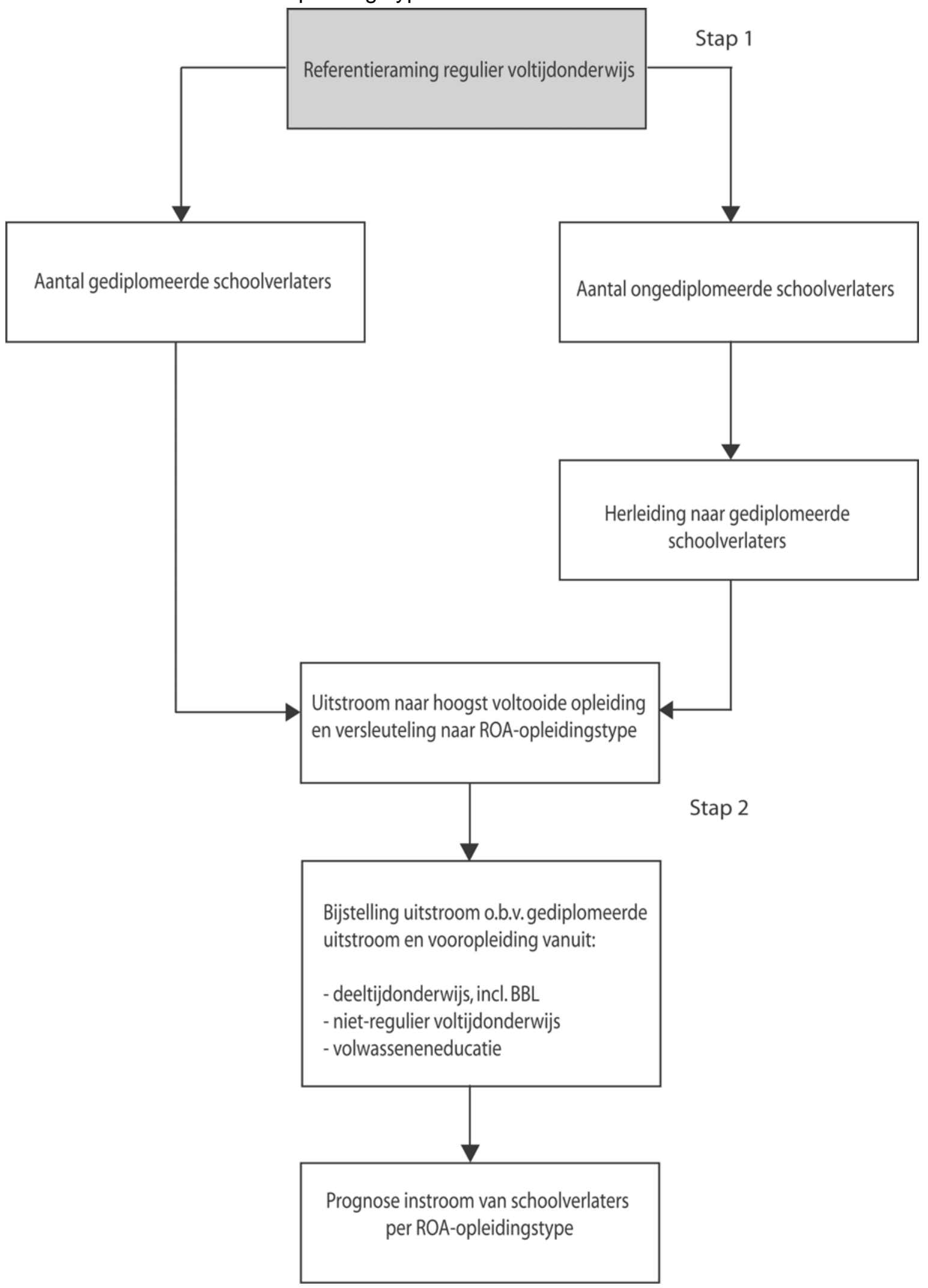


Figuur 4.5 geeft een overzicht van de opzet van stap 1 van het prognosemodel. De gebruikte databronnen zijn weergegeven in de grijsgetinte vakken. Uitgangspunt bij de bepaling van de verwachte toekomstige instroom van schoolverlaters op de arbeidsmarkt is de beleidsarme variant van de Referentieraming van het Ministerie van Onderwijs, Cultuur en Wetenschap (2005). Uit de Referentieraming worden de prognoses van het aantal schoolverlaters naar schoolsoort en -richting voor het voltijdonderwijs gebruikt. Hierbij is in de Referentieraming een onderscheid gemaakt tussen de schoolverlaters met diploma en de schoolverlaters zonder diploma. Degenen die het regulier voltijdonderwijs zonder diploma verlaten, kunnen eerder een opleiding met diploma hebben afgesloten. De ongediplomeerde schoolverlaters worden daarom toegewezen aan hun eerdere hoogst voltooide vooropleiding in het voltijdonderwijs. Deze hoogst voltooide voltijdopleiding wordt vastgesteld aan de hand van de Onderwijsmatrix 2003 van het CBS Dit resulteert in het verwachte aantal schoolverlaters met diploma per opleidingsniveau en -richting. ${ }^{18}$

De indeling van opleidingen op basis van de Onderwijsmatrix heeft een hoger aggregatieniveau dan de indeling die het ROA hanteert. Daarom vindt er een uitsplitsing plaats om de toekomstige uitstroom uit het regulier voltijdonderwijs naar de arbeidsmarkt per ROA-opleidingstype te bepalen. Deze verdeling wordt gemaakt met behulp van gegevens over het aantal gediplomeerden van elk opleidingstype binnen een schoolsoort, de CBS-werktabellen. ${ }^{19}$ De gebruikte gegevens hebben betrekking op de meest recente vijfjaarsperiode. Op basis van deze gegevens wordt door middel van 'exponential smoothing' de verwachte trend in het aantal gediplomeerden per opleiding voor de periode tot 2010 berekend, daarbij rekening houdend met de randtotalen uit de Referentieraming.

In de CBS-werktabellen worden de gediplomeerden op twee aggregatieniveaus weergegeven. Op basis van het hogere aggregatieniveau worden de CBS-werktabellen aan de Referentieraming gekoppeld en op basis van het lagere niveau wordt de procentuele verdeling berekend waarmee de gegevens uit de Referentieraming worden vermenigvuldigd. Voordat dit gebeurt wordt er nog een correctie uitgevoerd op de werktabellen. Omdat namelijk niet alle gediplomeerden schoolverlaters zijn, kan de verdeling van het aantal gediplomeerden afwijken van de verdeling van het aantal schoolverlaters. Op basis van de gegevens uit de VO Monitor, BVE Monitor, de HBO Monitor en de WO Monitor (kortweg SISgegevens) wordt het aandeel schoolverlaters binnen de groep gediplomeerden bepaald. Met deze gegevens wordt vervolgens de verdeling van de gediplomeerden over de opleidingsrichtingen binnen de schoolsoorten bijgesteld in de CBS-werktabellen. Ten slotte wordt met behulp van de SOI-codes (zie bijv. de ROA-classificatiegids 2002), behorende bij de

18. Voor MBO-schoolverlaters is een opsplitsing naar richting niet mogelijk.

19. De cijfers van de lagere en middelbare beroepsopleidingen zijn op basis van CFI-tellingen van het Ministerie van OCW vastgesteld en kunnen aan de hand van CREBO-codes gekoppeld worden aan de SOI '78 van het CBS. Voor het Hoger Onderwijs zijn de cijfers vastgesteld op basis van tellingen van de Informatie Beheer Groep, welke met behulp van CROHO-codes aan de SOI '78 worden gekoppeld. 
opleidingen in de CBS-werktabellen, de indeling op het laagste aggregatieniveau volgens de ROA-indeling berekend.

Op de resulterende prognoses wordt nog een laatste correctie uitgevoerd. ${ }^{20}$ Personen die na een bepaalde periode van afwezigheid terugkeren in het onderwijs worden in de Referentieraming als schoolverlaters beschouwd terwijl zij in feite doorstuderen. Aan de hand van gegevens van het CBS over de opleidingsachtergrond van deze groep, wordt er gecorrigeerd worden voor de zogenaamde indirecte instroom in een opleiding (zie Cörvers en Golsteyn, 2003). Na stap 1 zijn de instroomprognoses voor schoolverlaters en afgestudeerden van het voltijdonderwijs gereed.

In stap 2 wordt, zoals reeds is aangegeven, de instroomprognose aangepast door rekening te houden met de doorstroom naar de beroepsbegeleidende leerweg (BBL, het voormalige leerlingwezen), het overige deeltijdonderwijs, het niet-reguliere voltijdonderwijs of de beroepsgerichte volwasseneneducatie. Om een prognose te maken van het aantal schoolverlaters van de beroepsbegeleidende leerweg, wordt als randtotaal de prognose uit de Referentieraming van de beroepsbegeleidende leerweg genomen. Dit randtotaal wordt opgesplitst door de aantallen schoolverlaters die aan de hand van de CBS-werktabellen naar opleidingsrichting met 'exponential smoothing' zijn voorspeld, als verdeelsleutel te gebruiken. Hierin verschilt de methodiek niet van de voltijdschoolverlaters van de beroepsopleidende leerweg (BOL). ${ }^{21}$

Voor het samenstellen van de prognoses van het aantal schoolverlaters dat uit het nietreguliere onderwijs op de arbeidsmarkt instroomt, is er ten opzichte van de prognoses voor de beroepsbegeleidende leerweg een aantal verschillen. In de eerste plaats zijn er geen randtotalen uit de Referentieraming beschikbaar voor deze schoolverlaters. Dit betekent dat de prognoses van het aantal schoolverlaters per opleidingstype die op grond van de gegevens uit de EBB zijn samengesteld, als absolute aantallen worden meegenomen in de instroomprognose.

20. Voor een uitvoerigere beschrijving van de methodiek, zie Cörvers en Golsteyn (2003).

21. De voorspelde aantallen per vooropleiding van de BBL-schoolverlaters worden echter vervolgens tot vervangingsvraag naar deze opleidingen gerekend (zie paragraaf 4.3). Dit komt doordat de BBL'ers als werkenden beschouwd worden. Indien zij hun opleidingsplaats verlaten, komt hun baan voor nieuwe werkende BBL-leerlingen. 
Figuur 4.5

Globaal overzicht van de eerste stap van de instroomprognoses van schoolverlaters op de arbeidsmarkt

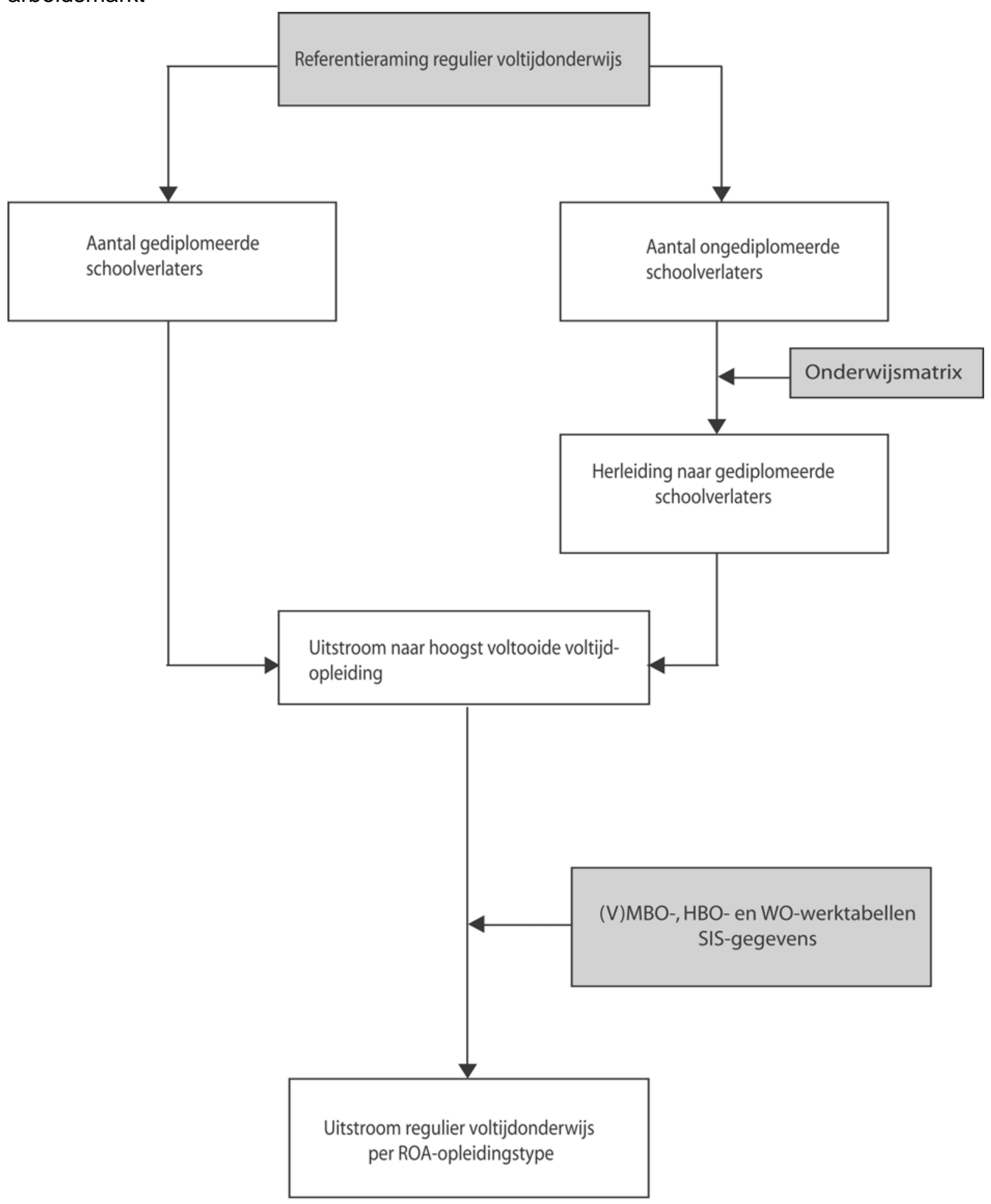


Ten tweede zijn er in het niet-reguliere onderwijs voltijd- en deeltijdschoolverlaters. Alle deeltijdschoolverlaters (die niet BBL volgden) worden tot het niet-reguliere onderwijs gerekend, en worden meegenomen in de instroomprognose volgens de hierboven vermelde methodiek. In de EBB zijn de schoolverlaters met niet-regulier onderwijs echter niet te onderscheiden van degenen met regulier onderwijs. Dit is van belang omdat de schoolverlaters van het reguliere onderwijs al in stap 1 zijn meegenomen. Op grond van De Grip en Jacobs (1999) behoren schoolverlaters tot het reguliere onderwijs als de schoolverlater en de gevolgde opleiding van de schoolverlater aan de criteria in tabel 4.1 voldoen. Ten opzichte van De Grip en Jacobs (1999) is afgeweken van het criterium van 4 jaar of langer voor de opleidingsduur van reguliere MBO-opleidingen. Ook MBO-opleidingen die 2 of 3 jaar duren kunnen worden beschouwd als regulier onderwijs (zie bijv. de Wet Educatie en Beroepsonderwijs).

Tabel 4.1

Criteria waaraan moet worden voldaan om een opleiding als regulier te definiëren

\begin{tabular}{lll} 
Opleidingsniveau & Leeftijd bij diplomering & Opleidingsduur \\
\hline & & \\
VMBO Theorie & $\leq 19$ jaar & \\
VMBO & $\leq 20$ jaar & \\
HAVO & $\leq 19$ jaar & \\
VWO & $\leq 20$ jaar & $\geq 2$ jaar \\
MBO & $<24$ jaar & $\geq 3$ jaar \\
HBO & $\geq 21$ jaar en $<30$ jaar & $\geq 4$ jaar \\
WO & $\geq 22$ en $\leq 30$ jaar & \\
\end{tabular}

Bron: bewerking van De Grip en Jacobs (1999)

Alleen schoolverlaters die buiten de criteria van tabel 4.1 vallen worden beschouwd als uitstroom uit het niet-reguliere onderwijs, en worden derhalve in stap 2 meegenomen als instroom op de arbeidsmarkt. Om een prognose te maken van het aantal schoolverlaters van het niet-reguliere onderwijs wordt gebruik gemaakt van de Enquête Beroepsbevolking van het CBS (EBB $2000 \mathrm{t} / \mathrm{m}$ 2003). Daartoe worden op SOI 5-digit niveau de personen geselecteerd voor wie geldt dat het actuele onderwijs ten opzichte van het hoogst behaalde onderwijs richting- en/of niveauveranderend is. Vervolgens wordt er op basis van de gegevens over de begindatum van de studie en de verwachte studieduur een schatting gemaakt van wanneer de studenten op de arbeidsmarkt instromen. Op dat moment wordt de hoogst behaalde opleiding op het moment van de enquête beschouwd als vooropleiding en de actuele opleiding als de hoogst behaalde opleiding.

Tot slot is het van belang op te merken dat degenen die niet-regulier onderwijs volgen en met een niet-reguliere opleiding op de arbeidsmarkt komen, zowel reeds werkend kunnen zijn als niet-werkend. Dit heeft consequenties voor de vervangingsvraag naar de vooropleiding van deze 'schoolverlaters'. Doordat de werkenden van opleidingsachtergrond veranderen ontstaat er, evenals bij de BBL'ers, vervangingsvraag naar hun vooropleiding. Bij de niet-werkenden ontstaat er echter geen vervangingsvraag naar de vooropleiding, maar een lagere arbeidsmarktinstroom van de betreffende vooropleiding. Zij kunnen dus als 
scholieren of studenten die in het niet-reguliere onderwijs zijn gaan doorstuderen worden beschouwd. De arbeidsmarktinstroom dient derhalve voor de opleidingstypen waarop deze vooropleiding betrekking heeft naar beneden te worden bijgesteld.

$\mathrm{Na}$ de bijstelling van de arbeidsmarktinstroom van het reguliere voltijdonderwijs met de arbeidsmarktinstroom van het BBL en het niet-reguliere onderwijs in stap 2 resulteert de toekomstige instroom van schoolverlaters op de arbeidsmarkt per ROA-opleidingstype voor de prognoseperiode 2005-2010.

\subsection{Baanopeningen en typering arbeidsmarktperspectieven}

Voor de opleidingen kunnen de verwachte vraag naar nieuwkomers en het verwachte aanbod aan elkaar worden gerelateerd. De verwachte vraag is gelijk aan het aantal baanopeningen dat in de prognoseperiode ontstaat als gevolg van de uitbreidings- en vervangingsvraag. Voor zover nieuwkomers op de arbeidsmarkt hinder ondervinden van een krimpende werkgelegenheid, wordt dit met de vervangingsvraag verrekend (zie paragraaf 4.3). De vervangingsvraag wordt immers alleen beïnvloed door de uitstroom van werkenden voor zover dit tot nieuwe vraag leidt.

Voor nieuwkomers op de arbeidsmarkt is de uitstroom van werkenden van de arbeidsmarkt alleen relevant indien door het verloop nieuwe vacatures ontstaan. ${ }^{22}$ Omdat ook de uitbreidingsvraag een netto-grootheid is geldt per definitie dat in geval van een groeiende werkgelegenheid de vervangingsvraag gelijk is aan het verloop. Als de werkgelegenheid krimpt, zijn er meer uitstromers dan instromers. Dit verschil is ook per definitie gelijk aan de (negatieve) uitbreidingsvraag. Het verband tussen vervangingsvraag en uitstroom ligt dus, bij een gegeven uitbreidingsvraag, vast. Er geldt:

vervangingsvraag $=$ uitstroom $+\operatorname{MIN}\{$ uitbreidingsvraag, 0$\}$

Op basis van deze identiteit kan het aantal baanopeningen op twee manieren worden vastgesteld. Ten eerste kan men uitgaan van de uitstroom en deze salderen met de uitbreidingsvraag:

baanopeningen $=$ uitstroom + uitbreidingsvraag

De tweede mogelijkheid is uit te gaan van de vervangingsvraag en hierbij indien er sprake is van een groeiende werkgelegenheid, de uitbreidingsvraag op te tellen:

baanopeningen $=$ vervangingsvraag $+\operatorname{MAX}\{0$, uitbreidingsvraag $\}$

Substitutie van de definitie van vervangingsvraag in de laatste vergelijking laat zien dat beide methodes gelijkwaardig zijn. De definitie op basis van de vervangingsvraag laat

22. Op de relatie tussen vacatures enerzijds en baanopeningen anderzijds wordt nader ingegaan in De Grip, Meijboom en Willems (1995). 
bovendien zien dat het aantal baanopeningen nooit negatief kan zijn. Naast het totaal aantal baanopeningen uit hoofde van uitbreidings- en vervangingsvraag wordt aan de vraagkant rekening gehouden met de substitutievraag (zie paragraaf 4.2).

Als aanbod op de arbeidsmarkt is de som genomen van de verwachte instroom in de periode 2005-2010 en het aantal werklozen aan het begin van de prognoseperiode dat korter dan 1 jaar werkloos is. Dit laatste is op te vatten als het boven de markt zwevende aanbod van werklozen aan het begin van de prognoseperiode. De bepaling van het aantal kortdurig werklozen is gebaseerd op het totaal aantal werklozen per opleidingstype volgens de EBB, vermenigvuldigd met het aandeel werklozen dat hooguit een jaar werkloos is. Dit aandeel is bepaald met behulp van gegevens van het Centrum voor Werk en Inkomen. ${ }^{23}$ Vervolgens wordt de Indicator Toekomstige Arbeidsmarktperspectieven (ITA) bepaald volgens de formule:

$$
I T A=\frac{(100+\text { instroom } \%+\text { kortdurig werklozen } \%)}{(100+\max \{0, \text { uitbreidingsvraag } \%\}+\text { vervangingsvraag } \%+\text { substitutievraag } \%)}
$$

Naarmate de waarde van de ITA hoger ligt, is er sprake van een slechter arbeidsmarktperspectief. Een waarde rond de 1 duidt op een evenwichtssituatie. Om te bewerkstelligen dat de grens tussen een goed en een redelijk perspectief precies bij 1 ligt en om discrepanties tussen de ITA en de typering te voorkomen, wordt de ITA naar boven afgerond (zie Wieling, De Grip en Willems, 1990).

\subsection{Typering knelpunten in de personeelsvoorziening}

\section{Knelpunten naar opleidingstype}

Naast de verwachte arbeidsmarktsituatie voor nieuwkomers is ook ingegaan op de verwachte knelpunten in de personeelsvoorziening. De indicator hiervoor is in principe het spiegelbeeld van de ITA. Als de vraag naar werkenden met een bepaalde opleidingsachtergrond groter is dan het aanbod kunnen knelpunten in de personeelsvoorziening verwacht worden. Vergelijkbaar met de Indicator Toekomstige Arbeidsmarktperspectieven (ITA) geeft de Indicator van de Toekomstige Knelpunten in de Personeelsvoorziening (ITKP) deze vraag-aanbodspanning aan. Bij een krimpende werkgelegenheid voor een bepaald opleidingstype wordt de totale vraag ('recruteringsbehoefte') echter op een enigszins andere wijze berekend dan het aantal baanopeningen voor nieuwkomers op de arbeidsmarkt. Verschil met de ITA is dat bij de ITKP de uitstroom van werkenden als gevolg van een krimpende werkgelegenheid is meegerekend in de vraag, omdat verwacht mag worden dat bij knelpunten in de personeelsvoorziening deze (gedwongen) uitstroom kan worden afgeremd

23. Met de EBB is het aandeel kortdurig werklozen niet goed te bepalen. De CWI-gegevens over nietwerkende werkzoekenden (NWW) laten echter geen betrouwbare differentiatie naar opleidingstype toe. Het aandeel kortdurig werklozen is met NWW-gegevens derhalve per opleidingsniveau bepaald. 
of elders werk zou kunnen vinden. Zeker wanneer bedrijven geconfronteerd worden met een krappe arbeidsmarkt voor een bepaald opleidingstype, zullen zij van deze mogelijkheid gebruik maken. Voor het overige is de Indicator Toekomstige Knelpunten in de Personeelsvoorziening (ITKP) gelijk aan de ITA. Naarmate de waarde van de indicator lager wordt, zijn de verwachte knelpunten in de personeelsvoorziening groter.

$$
I T K P=\frac{(100+\text { instroom } \%+\text { kortdurig werklozen } \%)}{(100+\text { uitbreidingsvraag } \%+\text { vervangingsvraag } \%+\text { substitutievraag } \%)}
$$

\section{Knelpunten naar beroepsgroep}

Voor het indiceren van de knelpunten in de personeelsvoorziening naar beroepsgroep kan niet een soortgelijke aanpak worden gevolgd, omdat het aanbod per beroepsgroep niet goed is vast te stellen. Daarom is een indicator ontwikkeld waarvoor geen voorspellingen van het arbeidsaanbod naar beroep nodig zijn.

De knelpunten in de personeelsvoorziening naar beroepsgroep nemen de prognoses van vraag en aanbod naar opleidingstype als uitgangspunt. Daarbij is als volgt te werk gegaan.

Het aanbod van een opleidingstype $i$ op tijdstip $t\left(\operatorname{aanbod}_{i, t}\right)$ is gelijk aan het aanbod op tijdstip $t$-1 (het 'basisjaar' van de prognoseperiode) plus de arbeidsmarktinstroom van schoolverlaters in de periode tussen $t-1$ en $t$ minus de vervangingsvraag over dezelfde periode:

$$
\operatorname{aanbod}_{i, t}=x_{i, t-1}+w_{l, t-1}+\operatorname{nieuw}_{i}-v v_{i}
$$

waarbij:

$$
\begin{array}{ll}
x_{i, t-1} & \text { het totaal aantal werkenden met opleiding } i \text { in } t-1 ; \\
w l h_{i, t-1} & \text { het aantal kortdurige werklozen met opleidingstype } i \text { in } t-1 ; \\
n i e u w_{i} & \begin{array}{l}
\text { de arbeidsmarktinstroom van schoolverlaters met opleidingstype } i \text { voor de } \\
\text { periode tussen } t-1 \text { en } t ;
\end{array} \\
v v_{i} & \begin{array}{l}
\text { de vervangingsvraag voor opleidingstype } i \text { in over de periode tussen } t-1 \text { en } t .
\end{array}
\end{array}
$$

De kans om een werknemer aan te trekken met opleidingstype $i$ wordt gegeven door:

$$
\begin{array}{ll}
p_{i}=\frac{\operatorname{aanbod}_{t, t}}{x_{i, t}} & \text { als aanbod } \text { alt } \leq x_{i, t} \\
p_{i}=1 & \text { als aanbod }{ }_{i, t}>x_{i, t}
\end{array}
$$


$x_{i, t}$ is de verwachte vraag naar opleiding $i$ op tijdstip $t$. We veronderstellen dus dat de kans om iemand met opleidingstype $i$ aan te trekken gelijk is voor alle beroepsgroepen. Dat betekent dat tekorten proportioneel over beroepen verdeeld zullen zijn.

De alternatieve indicator voor de toekomstige knelpunten in de personeelsvoorziening naar beroepsgroep $\left(I T K B_{j}\right)$ als gevolg van aanbodtekorten bij opleidingen waaruit de werkenden in beroep $j$ worden gerecruteerd, wordt dan gegeven door:

$$
I T K B_{j}=\frac{\sum_{i} p_{i} x_{i j, t}}{\sum_{i} x_{i j, t}} ; \quad 0 \leq \operatorname{ITKB}_{j} \leq 1
$$

De $I T K B_{j}$ is een relatieve maatstaf voor knelpunten. De noemer geeft de totale vraag vanuit beroepsgroep $j$ en de teller de verwachte vervulling van deze vraag. De $I T K B_{j}$ geeft dus de mate waarin de vraag vanuit beroepsgroep $j$ in de gewenste samenstelling vervuld zal kunnen worden. Naarmate de waarde van $I T K B_{j}$ lager is, zijn er meer knelpunten te verwachten. Als $I T K B_{j}=1$ dan worden er geen knelpunten verwacht bij het vervullen van de vraag vanuit beroepsgroep $j$. Een $I T K B_{j}$ van 0 betekent derhalve dat de vraag vanuit beroep $j$ in het geheel niet vervuld kan worden.

Deze indicator heeft echter een nadeel. De indicator geeft aan in welke mate het mogelijk is om de gewenste personeelsamenstelling te bereiken maar houdt geen rekening met de mogelijkheid om tekorten bij een opleiding aan te vullen door mensen met een andere (aanverwante) opleiding te rekruteren. Met eventuele substitutieprocessen wordt dus geen rekening gehouden. Dit impliceert dat een eventuele vermindering van de knelpunten als gevolg van passief substitutie-aanbod vanuit andere opleidingen in deze alternatieve indicator niet tot uiting komen.

\section{De structurele arbeidsmarktsituatie}

\subsection{Inleiding}

Naast de informatie over de actuele arbeidsmarktsituatie en de prognoses voor de ontwikkelingen op de arbeidsmarkt voor de middellange termijn, verschaft het informatiesysteem onderwijs-arbeidsmarkt ook inzicht in de structurele arbeidsmarktpositie van beroepsgroepen en opleidingstypen. Deze indicatoren beogen de kracht of kwetsbaarheid van een bepaalde beroepsgroep of opleidingsachtergrond op de arbeidsmarkt aan te duiden, ongeacht de specifieke actuele situatie of de voorspelde ontwikkelingen in de vraag-aanbodverhoudingen.

Het gaat hierbij om de indicator voor de conjunctuurgevoeligheid van de werkgelegenheid en de indicatoren voor de uitwijkmogelijkheden op de arbeidsmarkt. Daarnaast is ook gebruik gemaakt van een indicator voor de substitutiemogelijkheden die werkgevers hebben tussen 
arbeidskrachten met uiteenlopende opleidingsachtergronden en de concurrentie-index die aangeeft welke opleidingen een sterke verwantschap vertonen in hun beroependomein.

In dit hoofdstuk worden deze indicatoren besproken. Eerst wordt de indicator voor de conjunctuurgevoeligheid gesproken. In de daarop volgende paragraaf wordt ingegaan op de indicatoren van en de substitutiemogelijkheden op de arbeidsmarkt en de uitwijkmogelijkheden. In de laatste paragraaf wordt ingegaan op de concurrentie-index.

\subsection{Conjunctuurgevoeligheid}

De indicator voor de conjunctuurgevoeligheid geeft aan in welke mate de werkgelegenheid voor een bepaalde beroepsgroep of opleidingstype fluctueert als gevolg van schommelingen in de werkgelegenheid van bedrijfssectoren. De conjunctuurgevoeligheid van bedrijfssectoren wordt vastgesteld op grond van: ${ }^{24}$

$C I_{s}=100 \sum_{t} \frac{\left|w_{s}^{t}-\bar{w}_{s}^{t}\right|}{w_{s}^{t}}$

waarbij:

$C I_{s} \quad$ conjunctuurgevoeligheid van bedrijfssector $s$;

$w_{s}^{t} \quad$ de werkgelegenheid in bedrijfssector $s$ in jaar $i$;

$\bar{w}_{s}^{t} \quad$ de trend van de werkgelegenheid in bedrijfssector $s$ in jaar $t$.

De trend wordt berekend als:

$$
\bar{w}_{s}^{t}=\frac{w_{s}^{t-1}+w_{s}^{t+1}}{2}
$$

De indicator wordt vastgesteld op basis van gegevens van het totale arbeidsvolume uit de Nationale Rekeningen voor de periode 1977 tot $2003 .{ }^{25}$ In de praktijk blijken echter de productieberoepen sterker beïnvloed te worden door deze schommelingen dan andere functies. Om hiervoor te corrigeren wordt het verband vastgesteld tussen de werkgelegenheidsfluctuaties in een beroepssegment $\Delta W_{p s}^{t}$ en de schommelingen in een bedrijfssector:

$$
\Delta W_{p s}^{t}=C_{p s}+\alpha_{p s} \Delta W_{s}^{t}
$$

Dit verband is geschat op basis van de EBB van 1996 tot 2003. $\alpha_{p s}$ geeft aan in welke mate de werkgelegenheid in een bepaald beroepssegment meefluctueert met de werkgelegen-

24. De conjunctuurindicator wordt hierbij genormeerd naar de waarde 1.

25. Zie CBS $(1995,1996)$ voor de oudere tijdreeksen. 
heid van de bedrijfssector. De conjunctuurgevoeligheid van een beroepsgroep $b$ is vastgesteld als: ${ }^{26}$

$$
C I_{b}=\sum_{s} \frac{W_{b s}^{2003}}{W_{s}^{2003}} \alpha_{p s} C I_{s}
$$

Hierbij is $p$ het beroepssegment dat beroepsgroep $b$ omvat. Omdat bij een aantal beroepen waarbij het aandeel in de werkgelegenheid in een bedrijfssector vrij klein is, de schattingen van $\alpha_{p s}$ vrij extreme waarden aannamen, is de randvoorwaarde gesteld dat $\alpha_{p s}$ tussen 0,3 en 3,0 moet liggen.

Omdat de werkgelegenheid van mensen met een bepaalde opleidingsachtergrond deels ook aanbodbepaald is, is een soortgelijke aanpak voor de berekening van de conjunctuurgevoeligheid van opleidingstypen niet zinvol. Om die reden is bij het bepalen van de conjunctuurgevoeligheid van een bepaald opleidingstype het gewogen gemiddelde genomen van de beroepsgroepen waarin degenen uit deze opleidingsachtergrond werkzaam zijn.

$$
C I_{o}=\sum_{b} \frac{W_{b o}^{2003}}{W_{o}^{2003}} C I_{b}
$$

\subsection{Uitwijk- en substitutiemogelijkheden}

Omdat er in het algemeen geen één-op-één-relatie bestaat tussen opleiding en beroep of tussen opleiding en bedrijfssector is het zinvol om aan te geven hoe breed het domein is waarin mensen met een bepaalde opleidingsachtergrond werk vinden. De maatstaf die hiervoor wordt gebruikt is de Gini-Hirschman-index. De spreiding van een opleidingstype over beroepsgroepen wordt aangegeven door:

$$
G H_{o}^{b e r}=\frac{1}{\sum_{b}\left(\frac{W_{o, b}}{W_{o}}\right)^{2}}
$$

Deze maatstaf kan geïnterpreteerd worden als het gestandaardiseerde aantal beroepen waarin men terecht komt. Bij een volledige concentratie van de werkgelegenheid in één beroepsgroep is de indicator gelijk aan 1. Bij een gelijke spreiding over $n$ beroepsgroepen is de indicator gelijk aan $n$. Bij een ongelijke spreiding tellen beroepsgroepen met een relatief laag werkgelegenheidsaandeel minder zwaar mee dan beroepsgroepen met een groot werkgelegenheidsaandeel. Op vergelijkbare wijze kunnen de uitwijkmogelijkheden van een opleidingstype of een beroepsgroep naar bedrijfssectoren worden vastgesteld.

26. Ook bij de beroepen en opleidingen wordt de conjunctuurindicator genormeerd naar de waarde 1 . 
Daarnaast wordt een indicatie gegeven van de substitutiemogelijkheden die een werkgever heeft in de selectie van mensen met een uiteenlopende opleidingsachtergrond. Daarbij is de spreiding van de werkgelegenheid in een beroepsgroep over de opleidingstypen als volgt vastgesteld:

$$
G H_{b}^{\text {subs }}=\frac{1}{\sum_{o}\left(\frac{W_{o, b}}{W_{b}}\right)^{2}}
$$

\subsection{Concurrentie-index}

Naast het feit dat een opleidingstype tot werk in meerdere beroepen kan leiden, kan er tussen de werkgelegenheid van opleidingstypen ook een overlap bestaan. De concurrentieindex die hiervoor wordt gebruikt (zie Borghans, 1992) is afgeleid van de Gini-Hirschmanindex en luidt als volgt:

$$
S_{o, o o}=\frac{\sum_{b}\left(\frac{W_{o, b}}{W_{o}}\right)\left(\frac{W_{o o, b}}{W_{o o}}\right)}{\sqrt{\sum_{b}\left(\frac{W_{o, b}}{W_{o}}\right)^{2} \sum_{b}\left(\frac{W_{o o, b}}{W_{o o}}\right)^{2}}}
$$

Deze index geeft aan hoe groot de kans is dat personen met een verschillende opleidingsachtergrond (respectievelijk $o$ en oo) in dezelfde beroepsgroep werkzaam zijn. Omdat bij opleidingstypen met een grote beroepenspreiding deze kans a priori reeds klein is, is deze voor beroepenspreiding gecorrigeerd.

\section{Literatuur}

Borghans L. (1992), A Histo-Topographic Map of the Dutch University Studies, ROA-W-1992/5E, Universiteit Maastricht.

Borghans, L. (1996), Effects of supply and demand on the employment structure, mimeo, Universiteit Maastricht.

Borghans, L., A. de Grip, H. Heijke (2000), Alice in prognoseland. Over de zin van arbeidsmarktprognoses, ROA-W-2000/6, Universiteit Maastricht.

Borghans, L., A. de Grip, E. Willems (1995), Herijking ROA-Informatiesysteem Onderwijs-Arbeidsmarkt, ROA-R-1995/1, Universiteit Maastricht.

Borghans, L., H. Heijke (1994), Een random-coëfficiënten-model voor het voorspellen van de beroepenstructuur van bedrijfstakken, ROA-W-1994/1, Universiteit Maastricht.

Borghans, L., H. Heijke (1996), Forecasting the Educational Structure of Occupations: a Manpower Requirement Approach with Substitution, Labour, Vol. 10, pp. 151-192. 
Borghans, L., E. Willems (1998), Interpreting Gaps in Manpower Forecasting Models, Labour, Vol. 12, pp. 663-641.

Centraal Bureau voor de Statistiek (1993), Standaard Beroepenclassificatie 1992, Sdu, Den Haag.

Centraal Bureau voor de Statistiek (1995), Nationale Rekeningen: gereviseerde reeksen 1977-1986, Voorburg/Heerlen.

Centraal Bureau voor de Statistiek (1996), Nationale Rekeningen: gereviseerde reeksen 1969-1976, Voorburg/Heerlen.

Centraal Bureau voor de Statistiek (1999), Enquête Beroepsbevolking 1998, Voorburg/Heerlen.

Centraal Planbureau (1990), ATHENA Een bedrijfstakkenmodel voor de Nederlandse economie, Werkdocument No. 30, Den Haag.

Centraal Planbureau (2004), Vier vergezichten op Nederland: Productie, arbeid en sectorstructuur in vier scenario's tot 2040, Bijzondere CPB-publicatie, Den Haag.

Centraal Planbureau (2004a), Arbeidsaanbod in de lange-termijnscenario's voor Nederland, CPBDocument 71, Den Haag.

Centraal Planbureau (2005), Werkgelegenheid en toegevoegde waarde per bedrijfstak, 2001-2020 en 2021-2040, Den Haag.

Centraal Planbureau (2005a), Centraal Economisch Plan 2005, Den Haag.

Cörvers, F., A. Dupuy, S. Dijksman, B. Golsteyn, M. Hensen (2004), Methodiek arbeidsmarktprognoses en -indicatoren 2003-2008, ROA-W-2004/2, Universiteit Maastricht.

Cörvers, F., B. Golsteyn (2003), De invloed van voortijdige schooluitval op de instroomprognoses van schoolverlaters op de arbeidsmarkt, ROA-W-2003/1, Universiteit Maastricht.

Cörvers, F., A. de Grip, H. Heijke (2002), Beyond manpower planning: a labour market model for the Netherlands and its forecasts to 2006, in: M. Neugart and K. Schömann (eds), Forecasting Labour Markets in OECD countries, Edward Elgar, pp. 185-223.

Cörvers, F. (2003), Labour market forecasting in the Netherlands: a top-down approach, in: S.L. Schmidt, K. Schömann, M. Tessaring (eds.), Early identification of skill needs in Europe, Cedefop Reference Series, Vol. 40, Thessaloniki, pp. 72-83.

Cörvers, F., H. Heijke (2004), Forecasting the labour market by occupation and education: Some key issues, ROA-W-2004/4, Universiteit Maastricht.

Cörvers, F., B. Kriechel, R. Montizaan (2006), Scenario-analyse van de vervangingsvraag, ROA-W2006/1, Universiteit Maastricht.

Cörvers, F., A. Dupuy (2006), Explaining the occupational structure of Dutch sectors of industry, 1988-2003, forthcoming as ROA working paper, Universiteit Maastricht.

Dupuy, A. (2006), Measuring Skill-upgrading in the Dutch Labor Market, ROA-W-2006/3E, Universiteit Maastricht.

Eijs, P. van, A. de Grip (1998) De ontwikkeling van het project onderwijs-arbeidsmarkt 1986-1998, ROA-W-1998/7, Universiteit Maastricht.

EIM (2005), Kleinschalig Ondernemen, editie april, Zoetermeer.

Engle, R.F., C.W.J. Granger (1987), Co-integration and error correction: Representation, estimation, and testing, Econometrica, Vol. 55, pp. 251-276 . 
Grip, A. de, L. Borghans, W. Smits (1998), Future Developments in the Job Level and Domain of High-skilled Workers, in: H. Heijke, L. Borghans (eds), Towards a Transparent Labour Market for Educational Decisions, Ashgate, Aldershot/Brookfield USA/Singapore/Sydney, 1998, pp. 21-56.

Grip, A. de, A. Jacobs (1999), De doorstroom van het initieel onderwijs naar het niet-initieel onderwijs, ROA-W-1999/3, Universiteit Maastricht.

Grip, A. de, P. Meijboom, E. Willems (1995), Vacatures, werkgelegenheidsontwikkeling en de vraag naar nieuwkomers op de arbeidsmarkt, in: Tijdschrift voor Politieke Economie, vol. 18, pp. 36-57.

Heijke, H., A. Matheeuwsen, E. Willems (2003), Clustering Educational Categories in a Heterogeneous Labour Market, Education Economics, Vol. 11, pp. 89-108.

Mark, N.C. M. Ogaki and D. Sul (2003), Dynamic Seemingly Unrelated Cointegration Regression, NBER Technical Working Paper, No. 292, Cambridge Massachusetts.

Ministerie van Onderwijs, Cultuur en Wetenschap (2005), Referentieraming 2005, Zoetermeer.

Researchcentrum voor Onderwijs en Arbeidsmarkt (1999), De arbeidsmarkt naar opleiding en beroep 2004, ROA-R-1999/8 en 8B, Universiteit Maastricht.

Researchcentrum voor Onderwijs en Arbeidsmarkt (2002), ROA-classificatiegids 2002, ROA-R2002/3, Universiteit Maastricht.

Researchcentrum voor Onderwijs en Arbeidsmarkt (2003), De arbeidsmarkt naar opleiding en beroep 2008, ROA-R-2003/11, Universiteit Maastricht.

Researchcentrum voor Onderwijs en Arbeidsmarkt (2005), De arbeidsmarkt naar opleiding en beroep 2010, ROA-R-2005/9, Universiteit Maastricht.

Researchcentrum voor Onderwijs en Arbeidsmarkt (2005a), Schoolverlaters tussen onderwijs en arbeidsmarkt 2004, ROA-R-2005/6 en 6B, Universiteit Maastricht.

Shah, C., G. Burke (2001), Occupational Replacement Demand in Australia, International Journal of Manpower, Vol. 22, pp. 648-663.

Shyrock, H.S., J.S. Siegel (1980), The Methods and Materials of Demography, U.S. Bureau of the Census, U.S. Printing Office, Fourth Printing (rev.), Washington D.C.

Wieling M.H., A. de Grip, E.J.T.A. Willems (1990), Een systematische kwalitatieve typering van arbeidsmarktinformatie, ROA-W-1990/8, Universiteit Maastricht.

Willems, E. (1999), Modelling Replacement Demand: a Random Coefficient Approach, ROA-RM1999/2E, Universiteit Maastricht.

Willems, E., L. Borghans, A. de Grip (1997), Exit or no entry? Replacement demand and shrinking employment, ROA, Paper for the EALE conference, Aarhus, Denmark.

Willems, E.J.T.A., A. de Grip (1993), Forecasting Replacement Demand by Occupation and Education, International Journal of Forecasting, vol. 9, nr. 2, pp. 173-185. 



\section{Appendix A}

De grenzen en typering hebben betrekking op de gegevens in het ArbeidsmarktInformatieSysteem (AIS).

Tabel A.1

Grenzen kwalitatieve typering bedrijfssectoren

\begin{tabular}{lcccc}
\hline Typering & $\begin{array}{c}\text { erg laag } \\
\text { t.o.v. laag }\end{array}$ & $\begin{array}{c}\text { laag t.o.v. } \\
\text { gemiddeld }\end{array}$ & $\begin{array}{c}\text { gemiddeld } \\
\text { t.o.v. hoog }\end{array}$ & $\begin{array}{c}\text { hoog t.o.v. } \\
\text { erg hoog }\end{array}$ \\
\hline Conjunctuurgevoeligheid & 0,46 & 0,90 & 1,10 & 1,25 \\
Verwachte uitbreidingsvraag (\%) jaarlijks & $-1,10$ & 0,50 & 0,90 & 1,70 \\
\hline
\end{tabular}

Tabel A.2

Grenzen kwalitatieve typering beroepsgroepen

\begin{tabular}{|c|c|c|c|c|}
\hline Typering & $\begin{array}{l}\text { erg laag } \\
\text { t.o.v. laag }\end{array}$ & $\begin{array}{l}\text { laag t.o.v. } \\
\text { gemiddeld }\end{array}$ & $\begin{array}{l}\text { gemiddeld } \\
\text { t.o.v. hoog }\end{array}$ & $\begin{array}{c}\text { hoog t.o.v. } \\
\text { erg hoog }\end{array}$ \\
\hline Uitwijkmogelijkheden bedrijfssectoren & 1,11 & 1,97 & 5,95 & 10,59 \\
\hline Substitutiemogelijkheden & 3,90 & 6,54 & 11,26 & 17,15 \\
\hline Conjunctuurgevoeligheid & 0,40 & 0,60 & 1,25 & 1,780 \\
\hline Verwachte uitbreidingsvraag (\%) jaarlijks & $-2,10$ & $-0,20$ & 1,60 & 2,80 \\
\hline Verwachte vervangingsvraag (\%) jaarlijks & 2,00 & 2,90 & 4,40 & 5,40 \\
\hline Verwachte baanopeningen (\%) jaarlijks & 2,80 & 4,00 & 5,20 & 6,40 \\
\hline Typering & $\begin{array}{l}\text { geen t.o.v. } \\
\text { vrijwel geen }\end{array}$ & $\begin{array}{l}\text { vrijwel geen } \\
\text { t.o.v. enige }\end{array}$ & $\begin{array}{c}\text { enige t.o.v. } \\
\text { groot }\end{array}$ & $\begin{array}{l}\text { groot t.o.v. } \\
\text { zeer groot }\end{array}$ \\
\hline ITKB & 0,985 & 0,979 & 0,970 & 0,925 \\
\hline
\end{tabular}


Tabel A.3

Grenzen kwalitatieve typering opleidingstypen

\begin{tabular}{|c|c|c|c|c|}
\hline Typering & $\begin{array}{l}\text { erg laag } \\
\text { t.o.v. laag }\end{array}$ & $\begin{array}{l}\text { laag t.o.v. } \\
\text { gemiddeld }\end{array}$ & $\begin{array}{l}\text { gemiddeld } \\
\text { t.o.v. hoog }\end{array}$ & $\begin{array}{c}\text { hoog t.o.v. } \\
\text { erg hoog }\end{array}$ \\
\hline Uitwijkmogelijkheden beroepsgroepen & 3,12 & 6,30 & 12,60 & 19,63 \\
\hline Uitwijkmogelijkheden bedrijfssectoren & 2,28 & 4,35 & 9,85 & 15,14 \\
\hline Conjunctuurgevoeligheid & 0,68 & 0,87 & 1,09 & 1,33 \\
\hline Verwachte instroom (\%) jaarlijks & 1,80 & 2,70 & 4,60 & 6,40 \\
\hline Verwachte uitbreidingsvraag (\%) jaarlijks & $-0,30$ & 0,30 & 1,40 & 2,50 \\
\hline Verwachte vervangingsvraag (\%) jaarlijks & 1,30 & 2,20 & 3,90 & 4,70 \\
\hline Verwachte baanopeningen (\%) jaarlijks & 2,50 & 3,30 & 4,50 & 5,50 \\
\hline Typering & $\begin{array}{l}\text { zeer goed } \\
\text { t.o.v. goed }\end{array}$ & $\begin{array}{l}\text { goed t.o.v. } \\
\text { redelijk }\end{array}$ & $\begin{array}{c}\text { redelijk } \\
\text { t.o.v. matig }\end{array}$ & $\begin{array}{c}\text { matig t.o.v. } \\
\text { slecht }\end{array}$ \\
\hline ITA & 0,85 & 1,00 & 1,05 & 1,15 \\
\hline Typering & $\begin{array}{l}\text { zeer groot } \\
\text { t.o.v. groot }\end{array}$ & $\begin{array}{c}\text { groot t.o.v. } \\
\text { enige }\end{array}$ & $\begin{array}{l}\text { enige t.o.v. } \\
\text { vrijwel geen }\end{array}$ & $\begin{array}{r}\text { vrijwel geen } \\
\text { t.o.v. geen }\end{array}$ \\
\hline ITKP & 0,85 & 1,00 & 1,05 & 1,15 \\
\hline
\end{tabular}

Tabel A.4

Grenzen kwalitatieve typering opleidingstypen en -richtingen schoolverlatersinformatie

\begin{tabular}{lcccc}
\hline Typering & $\begin{array}{c}\text { erg laag } \\
\text { t.o.v. laag }\end{array}$ & $\begin{array}{c}\text { laag t.o.v. } \\
\text { gemiddeld }\end{array}$ & $\begin{array}{c}\text { gemiddeld } \\
\text { t.o.v. hoog hoog t.o.v. } \\
\text { erg hoog }\end{array}$ \\
\hline
\end{tabular}

Participatie in vervolgopleidingen studie Participatie in vervolgopleidingen BBL Percentage deeltijdarbeid Percentage met een vast dienstverband Intredewerkloosheid van 4 mnd of langer Percentage werkloosheid Onderbenutting Functie buiten de eigen vakrichting Gemiddeld bruto maandloon vmbo Gemiddeld bruto maandloon havo/vwo/mbo Gemiddeld bruto maandloon hbo Gemiddeld bruto maandloon wo

$\begin{array}{cccc}4,48 & 12,07 & 29,04 & 49,84 \\ 1,79 & 4,28 & 13,05 & 41,27 \\ 5,52 & 12,94 & 46,06 & 68,60 \\ 41,21 & 50,64 & 69,53 & 86,47 \\ 1,61 & 7,21 & 15,13 & 19,75 \\ 0 & 3,26 & 8,02 & 14,05 \\ 4,51 & 20,95 & 39,05 & 51,32 \\ 5,96 & 14,63 & 36,66 & 49,56 \\ \star & 773 & 897 & 1.219 \\ 1.208 & 1.313 & 1.569 & 1.797 \\ 1.831 & 1.899 & 2.050 & 2.254 \\ 2.176 & 2.240 & 2.383 & 2.729\end{array}$

Er worden vijf typeringen onderscheiden: erg laag, laag, gemiddeld, hoog en erg hoog. Bij de Indicator toekomstige arbeidsmarktsituatie (ITA) betreft dit: zeer goed, goed, redelijk, matig, slecht en met betrekking tot de Indicator toekomstige kans op knelpunten in de personeelsvoorziening (ITKP): zeer groot, groot, enige, vrijwel geen, geen. Voor alle variabelen, met uitzondering van de ITA, de ITKP en de ITKB, zijn grenzen bepaald op basis van de kwantielenmethode (zie ook Wieling, De Grip en Willems, 1990). Bij de kwantielenmethode worden de grenzen zodanig bepaald dat $10 \%$ in de klasse erg laag valt, 
$20 \%$ in laag, $40 \%$ in gemiddeld, $20 \%$ in hoog en $10 \%$ in de klasse erg hoog. Voordat een procentuele variabele wordt gekwalificeerd, wordt het percentage afgerond. Voor de grenzen voor de ITKB is de procentuele verdeling van de opleidingstypen over de typeringen die voor de ITKP gelden bepaald. Deze verdeling is opgelegd aan de knelpunten naar beroep. Als bijvoorbeeld $34 \%$ van de opleidingen gekenmerkt wordt door zeer grote knelpunten, wordt de grens tussen grote en zeer grote knelpunten bij de ITKB zodanig vastgesteld dat $34 \%$ van de beroepen ook de typering zeer grote knelpunten krijgt. 